\title{
Racism as Subjectification
}

\section{David Schraub*}

Nobody likes to feel used. But everyone likes to feel useful. This paradox has long been overlooked by people examining the parameters of racism in the United States. The classic model of racism focuses on the manner in which Black Americans have been objectified - and for good reason. From chattel slavery to Jim Crow, African Americans have faced a long and sordid history of being regarded as little more than objects-useful tools for White powerbrokers, but not independent subjects with their own desires, perspective, and rights.

However, following the Civil Rights revolution, this dynamic has shifted. While racial objectification has by no means disappeared, today the prevailing sentiment in American society is one that, outwardly at least, respects the independence and inherent dignity of its minority members. Yet, even as they are granted the full rights of citizenship, the idea that racial minorities are objectively valuable - are necessary to the full and complete functioning of society - has faded away. While admitting that racial minorities have inherent dignity and human rights, White society nevertheless denies that members of these groups have any objective use. If their presence is lacking in political, economic, and social institutions, it is not seen as a cause for concern. This is the problem of subjectification - when people who are conceded to possess subject status are nevertheless treated as if they have no objective worth. In this essay, I articulate the concept of subjectification and show how it provides a new and fruitful perspective on the problems of race and racism in American society.

INTRODUCTION.

DOI: http://dx.doi.org/10.15779/Z38W267

* Darling Foundation Fellow in Public Law, University of California-Berkeley School of Law. Rosalind Dixon, John Hall, Bob Keating, Eva Lam, Anna Moltchanova, Martha Nussbaum, Jillian Rodde, Kim Smith, Julie Suk, and Sarah Toews gave very useful and appreciated comments. This essay also benefited from feedback during talks at Carleton College, the University of Virginia, and the University of Chicago. Earlier drafts were assisted by a generous grant from Carleton College's Class of ' 63 Fellowship. Special thanks to Lauren Leonard, without whom this essay quite literally would never have been written. 
I. OBJECTIFICATION VERSUS SUBJECTIFICATION........................................... 7

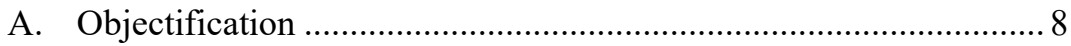

1. Objectification in Theory ......................................................... 8

2. Racism and Objectification................................................... 10

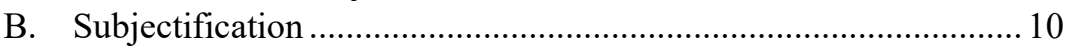

1. Subjectification in Theory …............................................... 10

2. Racism and Subjectification ................................................. 16

a. Subjectification in American life ..................................... 17

b. Why should we care about subjectification?...................... 18

C. "Objective" and "Subjective": A Brief Clarification ........................20

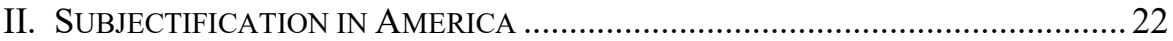

A. Diversity and the Problem of Subjectification ............................... 22

B. The Anti-Subjectification Turn......................................................29

III. IMPLICATIONS OF THE ANTI-SUBJECTIFICATION STANCE .............................. 34

A. Anti-Subjectification and the Law ................................................. 35

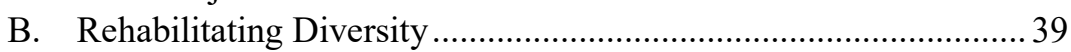

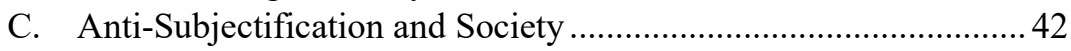

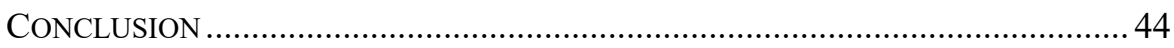

\section{INTRODUCTION}

Seeking to provoke debate, a college sophomore pens a newspaper editorial viciously attacking the school's affirmative action program. Students of color at the university, he argues, did not gain admission on the basis of merit. Instead, they are present as a sop to liberal college administrators and politically correct parents, who demand that a requisite number of dark faces be enrolled before the school can truly be considered "elite." Certainly, he concedes, a few of these students are at the school "legitimately," and he strongly disavows the position that the college should not admit qualified Blacks, Latinos, or Native Americans. But by and large, the author concludes, the men and women in question are mismatched at a program above their level, are being used as tools by the White majority, and both the students and college would be better off if they were not there at all. ${ }^{1}$

Unsurprisingly, the students of color on campus react with outrage. But their response takes two somewhat divergent threads. On the one hand, most respond indignantly to the suggestion that they somehow didn't "earn" their place at the university. They recite the long and impressive list of accomplishments from the resumes of the Black, Latino, Asian, and Native American student body - both before and since they were admitted. They note

1. Cf. Richard H. Sander, A Systematic Analysis of Affirmative Action in Law Schools, 57 STAN. L. REV. 367 (2004). I do not mean to suggest that Professor Sander's article is the equivalent of a brash college sophomore - only that he has made a related argument in a far more sophisticated form. 
that many alumni of color have gone on to distinguished careers and reached the highest levels of their professions, and stress that their success rate was right on track with their White peers. And they wryly question whether the author is absolutely confident in his own qualifications - how much of that SAT score reflected his innate intelligence, and how much was from that $\$ 1,000$ prep course he took the summer before? ${ }^{2}$ This group of students is firm and unrelenting: they are nobody's tool.

However, a significant chunk of the targeted students, while signing on to the previous statement, is also somewhat uncomfortable with it. Though these students are every bit as proud of their achievements as their more outspoken peers, they are equally as troubled by the implication that their presence isn't necessary as they were by the argument that it isn't deserved. After all, hadn't they just fought and won a long battle with the school administration to create a vigorous ethnic studies program, on the grounds that no student could claim a complete, liberal arts education without learning from the unique perspective of minority groups? While certainly unwilling to concede that their presence is wholly a function of their "usefulness" to their fellow students, this group is not prepared to say that their presence was extraneous either. They are needed, and they stressed that their fellow students and the college as a whole would suffer if their compatriots decided to depart for greener pastures.

This story highlights an interesting paradox. Nobody wants to feel used, but everyone wants to feel useful. Being respected as a subject, with individual worth and merit, is important. But it isn't sufficient to establish a fully adequate sense of personhood. On top of the need to be treated as moral subjects, people also demand that their objective value be respected as well. ${ }^{3}$ When people are not treated as if they are necessary to others, that their presence is optional or superfluous to the broader functioning of society, this exacts a significant moral toll of its own. This is the problem of subjectification, and it articulates a new way of understanding modern-day racial hierarchy.

Subjectification, defined very briefly, occurs when a person who has been accorded subject-status is not recognized to possess any objective worth. It is, in effect, the conceptual opposite of the well-known problem of objectification. Objectified persons are valued solely based on their usefulness to other people-for instance, as tools for manual labor, sexual desire, or reproduction-while being denied any recognition of their worth as human subjects with rights, agency, and personal autonomy. A subjectified human being, by contrast, is understood to possess all the basic rights or dignity accorded to people just for being persons. However, he or she is not seen as having any instrumental value to other people. This essay claims that

2. See Richard Delgado, Ten Arguments Against Affirmative Action-How Valid? 50 ALA. L. REV. 135, 153 (1998).

3. Or to put it another way, we want to be wanted; and we need to be needed. See Cheap Trick, I Want You To Want Me (Kendun Recorders 1977). 
subjectification accurately describes a significant portion of the racial subordination faced by people of color today, and that framing contemporary anti-racism discourse around this fact can yield significant gains for reformers and practitioners looking to defend or promote the interests of racial equality.

It should not surprise us that racism has shifted its contours from an objectifying to a subjectifying form. Racism, in the words of John Solomos and Les Back, is a "scavenger ideology, which gains its power from its ability to pick out and utilise ideas and values from other sets of ideas and beliefs in specific socio-historical contexts." ${ }^{4}$ With the discrediting of classical, scientific racism in the wake of World War II, ${ }^{5}$ the ideology of racism adapted to find new mechanisms for replicating the exclusion of people of color that were not dependent on assertions of biological inferiority. Instead of asserting that racial minorities must be officially excluded, the new paradigm claims to be apathetic towards whether they are included or not. That the status quo is one where they remain excluded is not itself of moral concern.

This essay proceeds in three parts. Part I introduces the concept of subjectification with reference to its cousin, objectification, and explores why it is a harm worthy of concern by anti-racism theorists. Because so many people around the world and across history have been and are oppressed by objectification, the problem of subjectification has been pervasively underexamined and often is not even recognized as a harm at all. Drawing on philosophical work by Leslie Green, Iris Marion Young, Martha Nussbaum, and others, I contend that recognition of one's objective value is essential to providing a full sense of personhood. America has made great strides in discrediting claims that racial minorities are unworthy of subject-status, but it has done little to provide for the concurrent recognition of their objective worth. This refusal harmonizes continued racial exclusion with contemporary meritocratic ideals: people of color should be included in a particular institution insofar as they are necessary and valuable to the success of that institution (that is, possess objective value); since they allegedly do not possess such value, their exclusion is acceptable (indeed proper).

In Part II, I apply the subjectification critique to the issue of diversity, focusing on affirmative action in colleges and universities, and the broader diversification of our democratic institutions. In both cases, I attempt to elucidate how the apathy (at best) White society shows towards diversifying these often heavily White institutions sends damaging messages to racial minorities regarding their instrumental worth, while being inconsistent with fundamental meritocratic principles. I also examine how the lens of subjectification provides a novel and effective way of defending diversity programs as they come under sustained attack from politicians and the courts. The anti-subjectification perspective can draw on well-established political

4. JOHN SOLOMOS \& LES BACK, RACISM AND SOCIETY 213 (1996).

5. See GeOrge M. Fredrickson, RACISM: A SHORT History 2-3 (2002). 
traditions that understand the value of heterogeneity and recognize how such values are properly incorporated into the meritocratic American ethos.

Finally, in Part III, I take stock of the broader implications of the antisubjectification stance, looking at how adopting it could change our perception of racial issues in the United States. Legally speaking, "meritocracy" is the watchword of contemporary equal protection law, and the challenge to diversity initiatives derives much of its force from the presumption that such programs violate meritocratic norms. The anti-subjectification perspective undercuts this claim and positions diversity initiatives as an unremarkable part of meritocratic decisionmaking-perhaps the strongest legal ground that remains to non-remedial race-conscious programs. From a social perspective, Americans continue to view race largely as a source of danger. Much of the appeal of color-blindness lies in its promise of sublimating that danger beneath promises of formal equality. Integration efforts, in turn, have been cast as morally imperative steps taken at great risk in service of higher ideals. These are two sides to the same coin, both of which cast Whites and non-Whites as fundamental adversaries on matters of racial justice. This certainly has a grain of historical truth to it, but it is not an eternal inevitability. The antisubjectification view encourages us to view race not just as a threat but also as a source of potential value. Such a view would represent a fundamental reorientation of how race is perceived in our community. It would help foster a climate that is more than tolerant, but affirmatively positive and welcoming towards the vast pluralities that make up the American experience.

\section{OBJECTIFICATION VERSUS SUBJECTIFICATION}

In this section, I use the more familiar concept of objectification as a reference point for introducing a new term: subjectification. Though the term and definition of subjectification were first mentioned in passing by Leslie Green, ${ }^{6}$ this essay represents the first sustained examination of the concept, as well as the first exploration of its connection to legal doctrine. What both critiques of objectification and critiques of subjectification have in common is a demand by marginalized persons that other people "acknowledge their worth."7 For an objectified person, this means recognizing that said person is valuable regardless and independent of what value they can produce for others. They are valuable simply because they are human, and that carries with it certain rights and attributes that need to be respected. For the subjectified individual, by contrast, the problem is not that they are denied certain rights, but rather are not recognized to be instrumentally valuable to other people or society at large.

6. Leslie Green, Pornographies, 8 J. PoL. PHIL. 27, 46 (2000).

7. Charles Taylor, The Politics of Recognition, in Multiculturalism: ExAmining THE Politics of RECOGNITION 25, 64 (Amy Gutmann, ed. 1994) (emphasis original). 


\section{A. Objectification}

\section{Objectification in Theory}

The concept of objectification came into mainstream usage after being developed by radical feminists such as Catherine MacKinnon and Andrea Dworkin. Objectification, in the view of these thinkers, is the frame by which men perceive women and exercise control over them. ${ }^{8}$ A person who is objectified is seen as having no value outside of that which they can give to others. They have no inherent dignity or worth. Mackinnon refers to objectification as allowing women to "grasp self only as thing." The practices of patriarchy made it easy to connect women's oppression to being possessed as a thing by men. ${ }^{10}$ As Iris Marion Young argues:

Feminists have had little difficulty showing that women's oppression consists partly in a systematic and unreciprocated transfer of powers from women to men. Women's oppression consists not merely in an inequality of status, power, and wealth resulting [from] men's excluding them from privileged activities. The freedom, power, status, and self-realization of men is possible precisely because women work for them. Gender exploitation has two aspects, transfer of the fruits of material labor to men and transfer of nurturing and sexual energies to men. ${ }^{11}$

Consequently, the objectifying frame became a central distinction between society's view of men versus women. While men were seen as agents and subjects, actors upon the world, women were seen primarily in functionalist terms - understood by reference to their usefulness to men. ${ }^{12}$

Martha Nussbaum identifies seven dimensions through which a person is objectified: instrumentality, denial of autonomy, inertness, fungibility,

8. See Rosalind Dixon, Feminist Disagreement (Comparatively) Recast, 31 HARV. J.L. \& GENDER 277, 282 (2008) (laying out the position of "[d]ominance feminists" as asserting that "female identity and the feminine as we know it are the pure products of a system of sexual subordination in which men defined themselves as subjects, and women as objects, via pornography and other systematic practices of male-to-female rape, prostitution, battering, and harassment.").

9. Catherine A. MacKinnon, Toward a Feminist Theory of the State 124 (1989). See also Andrea Dworkin, Against the Male Flood: Censorship, Pornography, and Equality, 8 HARV. WOMEN's L.J. 1, 15 (1985) ("Objectification occurs when a human being, through social means, is made less than human, turned into a thing or commodity, bought and sold.").

10. For example of the continued salience of objectification serving as a barrier to female empowerment, see Tamar Saguy, Diane M. Quinn, John F. Dovidio, \& Felicia Pratto, Interacting Like a Body: Objectification Can Lead Women to Narrow Their Presence in Social Interactions, 21 PSYCH. SCI. 178 (2010) (finding that women who believe they are being viewed as a body by men are likely to narrow their profile in social interactions).

11. Iris Marion Young, Justice AND the Politics of Difference 50 (1990) [hereinafter YOUNG, DIFFERENCE].

12. Susan Moller OKin, Women in Western Political Thought 10 (1979) ("Philosophers who... have asked 'What are men like?' 'What is man's potential?' have frequently, in turning to the female sex, asked 'What are women for?"'). 
violability, ownership, and denial of subjectivity. ${ }^{13}$ These together constitute the "loose cluster-term" of objectification, though Nussbaum suggests it is unclear whether only one or some combination of several factors is required to say that an entity is being "objectified." 14 Objectification, presumably, stands in opposition to one being recognized as a moral subject. A full moral subject, then, is one who is considered to be autonomous, valued regardless of her instrumentality, active, inviolable, containing inherent dignity, and possessing an independent moral perspective.

Two of Nussbaum's factors have particular importance for our purposes: instrumentality and fungibility. Nussbaum defines instrumentality as when "the objectifier treats the object as a tool of his or her purposes." ${ }^{15}$ Instrumentality, I feel, is the core element of objectivity - an object is fundamentally something that is used in some way, for some purpose. It also the one feature amongst Nussbaum's seven that she concludes is always morally problematic. ${ }^{16}$ Fungibility is important to clarify because of how it will relate to the idea of subjectification. Nussbaum identifies fungibility as treating "the object as interchangeable (a) with other objects of the same type, and/or (b) with objects of other types." 17 This requires some expansion. Fungibility, when talking about objects, presumes functionality. That is to say, the object is interchangeable with any other object (of any type) that would fulfill its function or role. The example she uses is that of a pen with another pen, or a pen with a word processor. ${ }^{18}$ There is no tie or bond to the particular pen, or even a pen versus any other tool that can transcribe words to a page. This is tied back into the presumption of instrumentality - any instrument that fulfills the role will do. But things that are seen to have no instrumental function are not properly labeled as "fungible," even though theoretically one could freely exchange any number of useless parts.

This leads to an interesting intersection between instrumentality and fungibility. Paradoxically, an object which is instrumental can simultaneously be seen as both replaceable and indispensable. Replaceable, because it can be switched with any object that would fulfill its role; indispensable, because without some object that fills the role, the desired action cannot be achieved.

13. Martha Nussbaum, Objectification, 24 PHIL. \& PUB. AFF. 249, 257 (1995) (defining each term). Consider also MacKinnon's formulation: that objectification "make[s] death-like that which is alive." Catherine A. MacKinnon, Not a Moral Issue, 2 YALE L. \& POL'Y REV. 321, 342 (1984).

14. Nussbaum, supra note 13, at 258 ("Should we say that each is a sufficient condition for the objectification of persons? Or do we need some cluster of the features, in order to have a sufficient condition? I prefer not to answer this question, since I believe that use is too unclear.").

15. Id. at 257.

16. Id. at $289-90$.

17. Id. at 257 .

18. Id. at 258. See also Margaret Jane Radin, Property and Personhood, 34 STAN. L. REV. 957, 959-60 (1982) (describing a fungible property as "an object that is perfectly replaceable with other goods of equal market value. One holds such an object for purely instrumental reasons"). 
Recognizing a pen as an object does not wed us to a particular pen, or even a pen versus a word processor, but it does indicate that some object that can transcribe words to a page is critical to the user's purposes.

\section{Racism and Objectification}

Racism as traditionally understood objectified its victims - it saw them merely as tools or resources to be used for the benefits of White power-brokers. The slave system was a clear instance of at least six of Nussbaum's seven categories of objectification (inertness is the possible exception). Instrumentality is one of the more important factors. Linking value to what one can do for others imperils a great number of the basic entitlements liberal society grants to individuals as part of our inherent human dignity. Once something (or someone) has been identified as a valuable tool, people will desire to own and control it (ownership, denial of autonomy). That which is owned can normally be treated or abused however the owner chooses (violation), and the reduction of person to property undoubtedly weakens the perception that they have a morally relevant perspective or experience (denial of subjectivity). Finally, because an instrument is valued only with regard to its function, it can be replaced by any object that replicates that function (fungibility). ${ }^{19}$ Overall, since objectified individuals are not seen as having intrinsic moral worth, it is easy to deny them political and legal rights. Persons whose value is perceived only in terms of what they can provide to others are not well-positioned to claim rights premised on inherent-and therefore "unearned"-human dignity.

This form of racism has not completely been eliminated today. However, the passage of various civil rights acts, the formal bar against de jure legal discrimination, and other such advances have sent the signal that racial minorities are subjects for the purpose of voting, political participation, and other metrics of societal inclusion. Much of the functional exclusion of racial minorities today comes not through a formalized commitment to exclusion, but rather from claims that it is morally irrelevant whether they are included or not.

\section{B. Subjectification}

\section{Subjectification in Theory}

To many, granting subject status to formerly objectified people is sufficient to affirm that we have secured their equal position in American society. After the 1960s, American discourse shifted rhetoric to at least an outward support of racial equality, ${ }^{20}$ and persons of all political stripes maintain

19. See Nussbaum, supra note 13, at 264-65 (explicating the link between the various elements of objectification and slavery).

20. MichaEl OMi \& Howard Winant, RaCial Formation IN THE UNited STATES: 1960-1990, at 117 (1994) ("With the exception of some on the far right, the racial reaction that 
a position in favor of at least some anti-discrimination laws and policies that prevent state actors from differentially treating people on the basis of race. Indeed, many trumpet this formalized equality as the ultimate proof that America has gotten beyond racism. ${ }^{21}$ Unlike in years past, non-White Americans can run for office, vote, attend school, serve on juries, and otherwise participate in the public sphere without any official handicap stemming from race. Within this color-blind framework, it is the acknowledgement of race that is the problem - and it is equally problematic regardless of source or motivation. $^{22}$

This view, in large part, respects the subject-status of people of color. It does not deny "their standing as civic subjects, applicants, supplicants, users or consumers." ${ }^{23}$ But yet, people demand more than mere recognition as subjects. If they are only seen as subjects, if they are granted no instrumental worth, that can be as debilitating and dehumanizing as if they are completely objectified. This is the problem of subjectification. Leslie Green explains:

Our instrumentality is one important part of our objectivity; it is the property of being of potential use to others who may direct us to their own purposes. This is not sufficient for our dignity as persons; but some who endorse a disembodied view of personhood would go further and say it is not necessary either. Interestingly, non-philosophers do not agree. Most people desperately want to be of use to others, and they come to understand themselves partly through those uses, actual and potential. Of course, they do not want only that, and they want to be of use and used subject to certain constraints - but the idea of being useful is in fact valued. Part of what is at stake when people age, when they are severely disabled, when they are chronically unemployed, is the fear that they are not, or they are no longer, useful. Others do not want them; they fulfill no valued role. They miss not only their diminished agency, but also their diminished objectivity. In dire cases people may no longer see themselves as something desired, wanted, or useful at all, even as they retain their standing as civic subjects, applicants, supplicants, users or consumers. They become, to coin a term, subjectified. ${ }^{24}$

developed in the last two decades claimed to favor racial equality. Its vision was that of a 'colorblind' society where racial considerations were never entertained in the selection of leaders, in hiring decisions, and the distribution of goods and services in general.").

21. See, e.g., Sumi Cho, Post-Racialism, 94 Iowa L. REV. 1589, 1595 n .13 (2009) (collecting sources proclaiming that the election of Barack Obama provided America's post-racial status).

22. See Antonin Scalia, The Disease as Cure, 1979 WASH. U. L.Q. 147, 153-54 (1979) (describing "the entire concept of 'restorative justice' as "racist," distributing debts based on the "blood that flows in our veins. ... affirmative action system ... is based upon concepts of racial indebtedness and racial entitlement rather than individual worth and individual need; that is to say, because it is racist."). See also id. at 157 ("From racist principles flow racist results.").

23. Green, supra note 6, at 46.

24. Id. at 45-46. Compare Abraham Joshua Heschel, Who Is Man? 58-59 (1965) ("[T]he old and sick [do not] expect help because of what they may give us in return. Who needs the old, the incurably sick, the maintenance of whom is a drain on the treasury of the state?"). 
In other words, whereas objectification is a state by which one is only seen with reference to their use to others, subjectification is a state by which one is not seen to have any use to others.

The notorious dangers of objectification often cause philosophers to overlook the benefits - indeed, the necessity — of also understanding oneself to possess objective worth useful to other people's projects. Instrumental value is relegated to the mundane, bloodless province of efficiency analysis and "commodification"- permissible perhaps for ordinary day-to-day interactions but deeply inappropriate for intimate, core areas of life. ${ }^{25}$ Implicit is the view that a sense of objective valuation could not itself be an important aspect of even deeply personal aspects of our identity. Objective valuation is viewed as at best a necessary evil, at worst a dehumanizing threat, but never itself the source of personal fulfillment and dignity.

As Green observes, "non-philosophers do not agree."26 Resisting subjectification - the social view that one is not valuable or useful or desirable to others - emerges in some of the most unexpected and deeply personal places. Green provides one example: he originated the term "subjectified" to refer to the status of gay men in the American social realm. ${ }^{27}$ Sexuality, of course, should (and does) tick off several red flags when thinking of the dangers of instrumentalization. It is a deeply personal element of one's intimate self, and its commodification has played a central role in the oppression of women. ${ }^{28}$ Nonetheless, in contrast to straight women who "rarely have difficulty seeing themselves as sex objects," ${ }^{29}$ a "motif" of gay male experience is the inability to perceive oneself as even a potential candidate for lust or desire. ${ }^{30}$ Gay men are either "invisible or non-existent", or are presented in a de-sexed light, as "fairies" or fops. ${ }^{31}$ As a result, Green argues, gay men "may lose or fail to

Heschel's point is the counter-weight - even when we have nothing to give, we still expect care because of our inherent dignity as human beings. But as people we still do not want to conceptualize ourselves as a drain on the resources of others. In addition to our desire to be respected as persons, we also want to be needed as persons.

25. See Nancy Leong, Racial Capitalism, 126 HARV. L. REV. 2151, 2199-2200 (2013) (identifying different views about whether and when commodification of certain traits is appropriate).

26. Green, supra note 6 , at 45 .

27. Id. at 45-46.

28. See, e.g., Margaret Jane Radin, Market-Inalienability, 100 HARV. L. REV. 1849, 1906 (1987) (identifying "politics, work, religion, family, love, sexuality, friendships, altruism, experiences, wisdom, moral commitments, character, and personal attributes" as being inappropriate subjects of commodification because they are "integral to the self). Cf. Leong, supra note 25 , at 2202 (" $[\mathrm{T}]$ he value associated with racial identity cannot, for example, be understood as an appropriate gift or subject of barter, in part because of the close linkage between racial experience and selfhood, and in part because the social meaning of such a transaction inevitably invokes the historical and ongoing racialized slavery in America.").

29. Green, supra note 6, at 46.

30. Id. at 47 (observing that "“coming out to oneself" means not just acknowledging one's own desires but also the harder work of seeing oneself as a possible object of the kind of desire that one has").

31. Id. at $46-47$. 
develop ... a robust sense of their own objectivity." ${ }^{32}$ In this situation, Green contends that pornography - being viewed and lusted after as "pure, dumb, meat" - takes on a decidedly different cadence. ${ }^{33}$ "As sexual beings gay men ... need to be treated as, and to be able to see themselves as, the possible object of another's desire. That is one of pornography's contributions, some of the time." 34 When one's sexuality is generally portrayed as "unnatural, disgusting, perverted, immoral, sick, or just plain weird," raw, unadulterated recognition that one is potential candidate for being lusted after is no small thing. ${ }^{35}$

A similar phenomenon can be found in sociological research regarding pregnancy among teens or poor unmarried women. Often viewed as purely pathological, researchers who have taken the time to actually interview these women have found that they often viewed the experience as positive and indeed critical to providing them with a healthy and self-affirming sense of personhood. ${ }^{36}$ Having another person who depends on them provides a sense a value, purpose, and direction that previously was missing. ${ }^{37}$ For women largely cut off from opportunities to have their objective value affirmed, having a child provides "a valid role and a meaningful set of challenges." 38 As one woman put it: "It's not for [welfare].... It's not even to keep the guy. It's just to have somebody... to take care of, or somebody to love...."39 More broadly, entering the role of a parent "reflect[s] a strategy to build community for themselves and to take their place in it as good citizens." ${ }^{40}$ In this constructed community, they can attain the otherwise elusive status of being valued, contributing members. The moral of this story is not, I think, that teen pregnancy (or pornography, for that matter) is inherently valuable. Rather it demonstrates that even in the most intimate and personal aspects of their lives,

32. Id. at 47 .

33. Id.at 46 (quoting DAVID CRAWFORD, EASING THE ACHE 145-46 (1991)).

34. Id. at 48 .

35. Id. at 47.

36. See, e.g., KATHRYN Edin \& MARIA J. Kefalas, Promises I CAN KeEP: Why PoOR Women Put Motherhood Before Marriage (2005); Clare J. Seamark \& Pamela Lings, Positive Experiences of Teenage Motherhood: A Qualitative Study, 54 BRIT. J. GEN. PRAC. 813 (2004).

37. See EDIN \& KEFALAS, supra note 36, at 172 ("These women rely on their children to bring validation, purpose, companionship, and order to their often chaotic lives - things they find hard to come by in other ways."); Seamark \& Lings, supra note 36, at 816 ("I didn't really know what I wanted to do [before], and I sort of didn't have any ambitions, whereas now I'm determined to go and make a success 'cos I have to for them.") (quoting a teen parent).

38. EDIN \& KeFAlas, supra note 36, at 172. See also Helen M. Alvare, Beyond the SexEd Wars: Addressing Disadvantaged Single Mothers' Search For Community, 44 AKRON L. REV. 167, 183 (2011) ("Single mothers often express gratitude to their child for giving them the opportunity to be of service.").

39. EDIN \& KEFALAS, supra note 36, at 172 (emphasis and ellipsis original).

40. Alvare, supra note 38, at 177 . To be clear, I agree with Alvare that a desire to be needed is not the only reason a woman from an at-risk background would choose to get pregnant. The fact that this perspective is a common one, however, is illustrative of the importance we all place upon feeling wanted in our communities. 
persons perceive objective value as constituting an important part of having a full and flourishing sense of self.

Other theorists have hinted at the concept of subjectification. In Justice and the Politics of Difference, Iris Marion Young examines what she terms "marginalization" as a facet of oppression. "Marginals," she writes, "are people the system of labor cannot or will not use." 41 She notes a variety of people who are "marginal," ranging from the old, to those who are not so old but get laid off and cannot find a new job, as well as poor men and women who can't find a first job, many disabled people, and Native Americans on reservations. ${ }^{42}$ "Marginalization," she proceeds, "is perhaps the most dangerous form of oppression. A whole category of people is expelled from useful participation in social life and thus potentially subjected to severe material deprivation and even extermination." 43

Of course, in the case of genocide, the problem of marginalization is not one of subjectification - at minimum, recognizing a being's subject-status should insulate them from casual, purposeful slaughter. However, Young identifies further, more subtle harms stemming from marginalization. She argues that, even if material inequities are eliminated, "marginalization is [still] unjust because it blocks the opportunity to exercise capacities in socially defined and recognized ways." 44 As Young correctly identifies, simply being part of "institutions that respect their freedom and dignity" is not sufficient to rectify the harms of marginalization, "which would remain in the form of uselessness, boredom, and lack of self-respect." 45 Even beyond that, true marginalization necessarily stunts the development of true self-identification, because the development of one's self image is often dependent on how one is seen by others. Drucilla Cornell describes Hegel's position that "[o]ne becomes a self-identified ego only through interaction in which one experiences oneself as a self by being mirrored in the eyes of others." ${ }^{46}$ Even hostile engagements would allow for this type of interaction, but not the outright indifference and unconcern faced by subjectified persons. In this respect, subjectification ends up sabotaging all but the most superficial sense of self (even as it purports to respect each person as a person), because it deprives people of even obtaining the recognition that others see them as a self who can be interacted and engaged with.

Nevertheless, by and large the concept of subjectification has escaped true critical examination. Because the idea of using someone as a tool or instrument

41. Young, DifFERENCE, supra note 11, at 53.

42. Id.

43. $I d$.

44. Id. at 54 .

45. Id. at 55 .

46. Drucilla Cornell, Toward a Modern/Postmodern Reconstruction of Ethics, 133 U. PA. L. REV. 291, 361 (1985). 
has such deep connections to the concept of objectification, ${ }^{47}$ progressive theorists understandably shy away from examining whether or not a person might suffer from a lack of any instrumental treatment. I do not deny the validity of these concerns. When attempting to dismantle hierarchal structures which "rank" certain people above others ${ }^{48}$ it feels dangerous to speak in the language of objective worth-for it seems apparent that some are objectively worth more than others. ${ }^{49}$ Thus, it appears safer to retreat into the language of subjective, inherent worth and dignity, which all people can be argued to possess equally. Moreover, some argue that the mentality of valuing things based on their usefulness is deadening. ${ }^{50}$ Abraham Joshua Heschel distinguished between manipulation and appreciation as the "two primary ways in which man relates himself to the world ...." 51 In the former, "he sees in what surrounds him things to be handled, forces to be managed, objects to be put to use. In the second way he sees in what surrounds him things to be acknowledged, understood, valued or admired." 52 Heschel argues that human solidarity requires appreciation, "while manipulation is the cause of alienation.... A life of manipulation is the death of transcendence." 53 Consequently, moral inquiry aimed at promoting the perceived instrumentality of others is likely to be viewed as suspicious at best, outright dangerous at worst. ${ }^{54}$

But not speaking of objectivity at all solidifies a different sort of hierarchy: those who are seen as possessing objective worth and those who are not. ${ }^{55}$ As with racism in general, avoiding the topic "may reduce consciousness

47. See Nussbaum, supra note 13, at 264-65 ("[T] he very decision to treat a person as not an end in him- or herself, but as a mere tool, leads rather naturally to a failure of imagination. Once one makes that basic move it is very easy indeed to stop asking the questions morality usually dictatesFalse"); Angela P. Harris, Theorizing Class, Gender, and the Law: Three Approaches, 72 L. \& CONTEMP. PROBS. 37, 52 (2009) (identifying "capitalism's great power, which from a moral standpoint is also its fatal flaw: its ability to turn all entities, including human beings, into objects - commodities - for others' profit").

48. See Frank Rudy Cooper, Against Bipolar Black Masculinity: Intersectionality, Assimilation, Identity Performance, and Hierarchy, 39 U.C. DAVIS L. REV. 853, 871 (2006) (defining the "epistemology of the scaling of bodies" as having three factors "(1) people must be categorized according to qualities such as gender, race, sex orientation, and so on; (2) the types within each category must be hierarchized; and (3) society must be structured based on those hierarchies.").

49. In a capitalist system, for example, those who are paid more are presumed to be worth more - more important, more indispensable - than those who are paid less. The language of objectivity thus runs the risk of reifying class hierarchy.

50. See Leong, supra note 25, at 2204 (articulating how "commodifying" race harms non-White persons).

51. HESCHEL, supra note 24 , at 82.

52. Id.

53. Id.

54. See, e.g., Leong, supra note 25, at 2213; James F. Blumstein, Grutter and Fischer: A Reassessment and a Preview, 65 VAND. L. REV. EN BANC 57, 64 (2012).

55. As Young's analysis of marginalization indicates, see text surrounding notes 41-45, the two hierarchies can coexist. One critic of affirmative action programs buttressed her case by citing the opinions of "Faculty, Students, and Beneficiaries." Lauren Arms, Comment, It's Not All 
of a problem, but... does not change the underlying reality." 56 Insofar as people perceive the problem of not being wanted, useful, productive, or socially valuable, only grappling with objectification will not fully deal with the ongoing effects of racism in American society. Fortunately, speaking in the language of objectivity can be reconciled with recognition of a person's subjective worth. As Nussbaum argues, recognizing an entity's instrumentality does not necessarily "entail lack of consideration for [their] feelings and subjectivity." 57 The very word "instrumental" may be clarifying: saying that I was "instrumental" to the success of a project is a high compliment. An important part of our sense of self-worth is feeling that we are indispensable in such a manner, that the role we play cannot be replicated, that the world cannot do without us. To a large extent, we do strive to be "instrumental" at least in part, though we do not wish for instrumentality to replace or subsume the inherent and unconditional dignity and respect we command as human beings. Neither subjectivity nor objectivity, alone, can fully respect our status as person.

\section{Racism and Subjectification}

The preceding discussion should have made clear that subjectification encompasses a descriptive as well as a normative component. Descriptively, the focus on subjectification suggests that our fellow citizens possess objective value, in terms of making our communities stronger, our colleges more vibrant, or our economies more robust. Along the axis of race, these questions have been well-explored in the empirical literature. ${ }^{58}$ The normative point, however, extends beyond this: we have a moral obligation to affirm the objective worth of our fellows. We must act in a way that demonstrates that we do recognize that our fellows are valuable in this respect.

Black and White: Race-Based Admissions Purport to Achieve a Critical Mass of Diversity, but in Reality Merely Mask a Pre-Determined Quota of the Ideal Integrated Society, 49 S. TEX. L. REV. 205, 230-32 (2007). On the one hand, separating the minority "beneficiaries" of affirmative action out from the general category of "students" diminishes the subjective value of those men and women, implying that they are not full and equal members of the academic community. On the other hand, falsely implying that only minority students are the "beneficiaries" of affirmative action attacks their objective value, rendering them parasitical and instrumentally worthless.

We should not be surprised that commentators who do not respect the dignity of minority persons along one axis also are cavalier with it along another. Still, most persons at least outwardly identify subjective equality as a key value they are trying to promote through their analysis. See, e.g., id. at 233 (claiming her project is aimed at disproving the assumption "that blacks or browns cannot make it on their individual merit. That is a stamp of inferiority that a State is not permitted to place on any lawyer. ... All races can compete fairly at all professional levels.") (quoting DeFunis v. Odegaard, 416 U.S. 312, 343 (1974) (Douglas, J., dissenting)).”““

56. Natsu Saito Jenga, Unconscious: The “Just Say No" Response to Racism, 81 IowA L. REV. 1503, 1504 (1996).

57. Nussbaum, supra note 13, at 260.

58. See infra Part II.B. 


\section{a. Subjectification in American life}

Proposition 209 was a 1996 California referendum that effectively banned affirmative action in the state. Specifically, it codified that "The state shall not discriminate against, or grant preferential treatment to, any individual or group on the basis of race, sex, color, ethnicity, or national origin in the operation of public employment, public education, or public contracting." 59 When California voters passed Proposition 209, the number of Black students admitted to UC-Berkeley's Boalt Hall law school plummeted from seventyseven the year before passage to eighteen the year after. Of these eighteen, none chose to enroll at Berkeley, leaving only one incoming Black student who had deferred his admission from the year before. ${ }^{60}$ In terms of their relationship to Boalt, Black students are quite obviously being subjectified. The virtual elimination of Black law students attending Berkeley did not have any noticeable impact on Boalt's reputation or status in the legal community. Few people suggested that the law school would be hampered in its job of training new lawyers, or would be providing an inferior class environment for its students, without Black people present. Several people claimed the opposite, denying that the presence of Black people was required to achieve Berkeley's mission as a university. ${ }^{61}$ What clearer message could be sent to prospective Black students that their presence is optional, unnecessary, and ultimately dispensable?

In subsequent years, the legal and political standing of affirmative action has continued to deteriorate. Anyone who subscribes to Derrick Bell's interestconvergence theory could explain why. ${ }^{62}$ While the desegregation of American schools did provide a significant boon in the educational prospects of young Black men and women, ${ }^{63}$ it was never seen as being in the interests of White middle-class parents, who viewed integration as a burden, hardship, or even danger to their children. Though given a brief reprieve in Grutter v. Bollinger - a reprieve that came with a self-imposed time limit $^{64}$ - the addition

59. California Constitution, Art. I, Sec. 31. For a good overview, history, and critique of the legal issues surrounding Proposition 209, see Girardeau A. Spann, Proposition 209, 47 DUKE L.J. 187 (1997).

60. Charles R. Lawrence, Two Views of the River: A Critique of the Liberal Defense of Affirmative Action, 101 CoLUM. L. REV. 928, 929 (2001).

61. See Amy DeVaudreuil, Silence at the California Law Review, 91 CAL. L. REV. 1183, 1184 (2003) (reviewing ANDREA GuERrERO, SilENCE AT BoAlt HALL: THE DisMANTLING OF AfFiRMATIVE ACTION (2002)) (citing a former Dean to that position).

62. Derrick A. Bell, Jr., Brown v. Board of Education and the Interest-Convergence Dilemma, 93 HARV. L. REV. 518 (1980) (arguing that Whites will only work for Black equality when it is in their own interests to do so).

63. Gary Orfield writes that "the desegregation era was a period in which minority high school graduates increased sharply and the racial test score gaps narrowed substantially until they began to widen again in the 1990s [when resegregation began in earnest]False" Quoted in KozOL, supra note 117 , at 19.

64. 539 U.S. 306, 343 (2003) (predicting that in twenty-five years, affirmative action will no longer be necessary or, presumably, constitutionally permissible). 
of two conservative justices has weakened the position of race-conscious integration yet further. In Parents Involved in Community Schools v. Seattle School District, ${ }^{65}$ four justices signaled their readiness to do away with raceconscious programs in education altogether. ${ }^{66}$ Only an expansive, yet cryptic, concurrence by Justice Kennedy staved off that outcome. ${ }^{67}$

With the entire idea of race-conscious programs in the educational sphere in danger, it is critical for defenders of affirmative action to try and find alternative arguments that can hold together its fragile coalition on the highest court. ${ }^{68}$ But while Professor Bell's theory closes off some avenues towards achieving racial reform (namely, those that focus on moral duty or benefits to students of color), it simultaneously opens up others. From an interestconvergence standpoint, after all, Whites should be willing to pursue diversity if they can be persuaded that it is in their interests to do so. It is unsurprising, then, that the debate over affirmative action has been waged increasingly on this battlefield. If the question is whether or not proactive diversity efforts are good for Whites as well as for racial minorities, then the answer given has profound implications (for good or ill) of how society views the objective value of people of color.

\section{b. Why should we care about subjectification?}

From the antebellum era and beyond, Black Americans were objectified, seen as having no intrinsic worth, while being "useful" as forced labor. ${ }^{69}$ While

65. 551 U.S. 701 (2007).

66. Id. at 711 (opinion of Roberts, C.J.). A narrow and temporary exception would have been carved out for remedial programs. Id. at 751 (Thomas, J., concurring).

67. Id. at 782 (Kennedy, J., concurring). For an analysis of the motivations and context of Justice Kennedy's concurrence, see Heather K. Gerken, Justice Kennedy and the Domains of Equal Protection, 121 HARV. L. REV. 104 (2007).

68. It has been argued that affirmative action and the integration push generally have been effectively neutralized to the point that it would be better to focus on new routes towards racial equality. James E. Ryan, The Supreme Court and Voluntary Integration, 121 HARV. L. REV. 131, 142 (2007) ("[T] he reality is that the Court has not issued a significant, favorable opinion regarding school desegregation in about thirty years. Some of these proposals have been both innovative and inspiring. For example, in a recent article Charles Lawrence III suggested expanding affirmative action programs to include children of any race who attended integrated schools. Charles R. Lawrence III, Forbidden Conversations: On Race, Privacy, and Community (A Continuing Conversation with John Ely on Racism and Democracy), 114 YALE L.J. 1353, 1396 (2005) (" $[\mathrm{U}]$ niversities, as part of their affirmative action programs and in pursuit of their goal of admitting students knowledgeable about and experienced in issues of diversity, might prefer both black and white students who had attended integrated schools.").

But, merits of these alternatives aside, there remains something inspirational in the idea that American institutions would voluntarily and of their own accord press for an integrated social sphere. Even if the tangible impacts of the Court's decisions restricting those ambitions are small, "it takes away some hopeFalse [and] it is no small thing to dash hope." Ryan, supra, at 133.

69. Of course, the objective value Blacks were recognized to possess existed only within this narrow band-Blacks were not seen as objectively valuable across all social institutions, just in this one particular role. Cf. Jennifer L. Hochschild, The Word American Ends in "Can": The Ambiguous Promise of the American Dream, 34 WM. \& MARY L. REV. 139, 150-51 (1992) ("For 
some Black leaders tried to take advantage of this sentiment, ${ }^{70}$ others rebelled against even well-meaning efforts by White benefactors whose programs emphasized Black "usefulness." "71 But to some extent today, the White perspective on Blacks has been reversed. ${ }^{72}$ Now, advocates for "colorblindness" couch their arguments in the form of protecting the intrinsic dignity of all citizens, while simultaneously apathetic to whether in fact the social circles they inhabit contain any non-White membership. Perfectly willing to grant people of color the technical status as "civic subjects, applicants, supplicants, users or consumers," this model nonetheless gives no credit to their instrumentality - if every non-White person disappeared tomorrow, the world would spin as normal. In effect, this split helps solve the "mainstream anxiety" resulting "from the conflict between its relatively recent public creed of inclusion and its continuing subconscious belief that most black men should be excluded." 73 However, in spite (or because) of its utility to Whites, this position is deeply damaging to racial minorities. It labels citizens of color as literally worthless and expendable. They have no value to society, they serve no useful purpose. This message has impressed itself on people of color. Cherrie Moraga, commenting on the role of women of color in the feminist movement, wrote "so often the women seem to feel no loss, no lack, no absence when women of color are not involved. ... This has hurt me deeply." 74

Neither objectification nor subjectification "change[s] the moral status of a person, for that is not a matter of social convention." 75 But in a world where one's objectivity or subjectivity is constantly questioned, it can be difficult for a person to become or remain aware of his or her possession of either. The

most of American history, being a woman, Native American, Asian, black, or pauper has barred people from all but a very narrow range of electable futures.") (internal quotations omitted).

70. See, e.g., BoOKer T. WAShington, Up From Slavery 99-100 (W.W. Norton 1996) (1901) (urging White southerners to "cast down your bucket where you are"-i.e., take advantage of the skills and labor of the Black men and women they already know).

71. Though many Black leaders in the early $20^{\text {th }}$ century were appreciative of any support they could find in a generally hostile climate, some still chafed under what they saw as "condescension" from White philanthropists who emphasized economic uplift rather than civil rights. See Eric L. Goldstein, The Price of Whiteness: Jews, RaCe, AND AmericAn IDENTITY 72 (2006). For example, the Niagara movement's demand that education be providing to Black youth stressed that "we mean real educationFalse We want our children trained as intelligent human being should be, and we will fight for all time against any proposal to education black boys and girls . . simply for the use of other people." Quoted in W.E.B. DU BOIS, DUSK OF DAWN 46 (Oxford UP 2007) (1940).

72. This corresponds with the broad evolution in racist conceptions of Blackness from the slave era to the current day. Cf. Tommie Shelby, Is Racism in the "Heart"? 33 J. Soc. PHIL. 411, 417 (2002) ("[D]uring the period of American slavery, black slaves were commonly thought to be docile, superstitious, easily satisfied, and obsequious, but in the present postindustrial phase of capitalist development, blacks are more often viewed as socially parasitic, full of (unjustified) anger, irresponsible, and dangerous.").

73. Cooper, supra note 48 , at 858 . $33(1983)$.

74. Cherrie Moraga, Refugees of a World on Fire, in THIS BRIDGE CALLED My BACK

75. Green, supra note 6 , at 45 . 
argument against subjectification, hence, is not a claim that marginalized people need - in a metaphysical sense - to be seen as valuable by Whites in order to fully self-actualize. As John Edgar Wideman stated, "I don't need to hate white people in order to love myself. But I also don't need hite people to tell me what I am or what I can strive to be or tell me if I've made it or not. I don't need to know a white person or know white people to make a good life for myself to be happy with myself or to love other people whatever color they may be or not be." 76 Rather, the argument against subjectification derives its force from three premises. First, in a racialized society, the social attitudes of dominant groups play a significant role in constructing even the self-image of the Other, something that remains socially true even if it is not metaphysically so. ${ }^{77}$ Second, regardless of how the Other views herself or himself, in a pluralist society a certain degree of interdependency is inevitable-doors and opportunities are closed (and opened) based on how the dominant caste perceives those around it. Hence, subjectification implicates a concern for maximizing opportunity for all citizens. ${ }^{78}$ Finally, even insofar as people of color can construct an adequate and sustainable account of their objectivity and subjectivity independent of White people, Whites would still have the obligation to battle against their own subjectifying attitudes for the simple reason that this is how one treats one's peers with respect. Our obligation to value other people - even to value their objectivity - is not premised on their willingness, ability, or even duty to give anything back to us. It is, in a sense, a gift, and "for there to be a gift, there must be no reciprocity, return, exchange, countergift, or debt." ${ }^{\text {" I }}$ In this way, the duty of Whites to oppose their subjectification of people of color in no way demands or implies a countervailing duty for racial minorities to join White society if they do not desire it. It does, however, create the opening for people of color to give such a gift of their own, if they so choose. ${ }^{80}$

\section{C. "Objective" and "Subjective": A Brief Clarification}

An important clarification is necessary before we proceed. The words "objective" and "subjective" each have at least two important and somewhat

76. Quoted in ROY L. BROOKS, INTEGRATION OR SEPARATION? 189 (1996).

77. See Taylor, supra note 7 , at 66 ("[D]ominant groups tend to entrench their hegemony by inculcating an image of inferiority in the subjugated. The struggle for freedom and equality must therefore pass through a revision of these images.").

78. Tommie Shelby, We Who Are Dark: The Philosophical Foundations of BLACK SOLIDARITY 48 (2005) (citing Martin Delany to the position that the disproportionate presence of Blacks in low-status roles leads others to view them "as a 'naturally' subservient people."). 1992).

79. JaCQues Derrida, Given Time: Counterfeit Money 12 (trans. Peggy Kamuf,

80. See Iris Marion Young, Intersecting Voices: Dilemmas of Gender, POLITICAL PHILOSOPHY, AND POLICY 54 (1997) [hereinafter Young, VoICES]. 
contradictory meanings that can obfuscate this discussion greatly. ${ }^{81}$ Grammatically speaking, a subject is an actor or user, while an object is something acted upon or used. In the sentence "Jean throws the ball", Jean is the grammatical subject (the actor) and the ball is the object (that acted upon). As generally articulated, objectification and subjectification refer to these definitions: an objectified person is one who is seen only as a thing, someone to be acted upon but who possesses no agency, while a subjectified person is someone seen only as an actor, someone who acts but would never be acted upon. Consequently, one's objectivity is one's status as someone that can be used and is seen as useful, and one's subjectivity is one's status as someone who is capable of using, directing, and manipulating.

But objective and subjective also have meanings related to epistemology and ontology. An objective truth remains true across time and space: it is a reality that exists separate from the perceptions and beliefs of individuals. By contrast, a subjective truth (or belief) is contingent on circumstance, situation, personal opinion, or outlook. These definitions speak to the metaphysical status of the concept, person, or proposition under discussion, as opposed to its social or grammatical relationship with those around it.

These definitional pairs are in tension. ${ }^{82}$ The objective worth of a person - their worth as an object-is subjective insofar as it doesn't exist outside particular contingent value judgments by other people, the social structures that give those judgments meaning and authority, etc. Meanwhile, the subjectivity of a person - their status as at least semi-autonomous, imbued

81. Though the two meanings explicated below are the ones most fraught with peril for the purposes of this essay, objective and subjective can and have taken on far more meanings than this. L.W. Sumner is not wrong when he claims "the concept of the subjective is one of the most treacherous in the philosopher's lexicon," noting that in "different contexts and for different purposes the realm of the subjective has been delineated by means of a number of features: privacy, immediacy, incorrigibility, unverifiability, unquantifiability, relativity, arbitrariness, reliance on judgment or intuition, and immunity to rational arbitration.” L.W. SUMNER, WELFARE, HAPPINESS, AND ETHICS 27 (1996).

82. This strain is aptly displayed in the following statement by Drucilla Cornell: "the objectifying tendency inherent in instrumental rationality threatens subjectivity." Cornell, supra note 46 , at 308 . "Objectifying", here, refers to the belief that the world is knowable and can be described in some metaphysically true sense (the epistemological definition). This threatens the subjectivity of persons as autonomous decision-makers, who are acting upon real objects (the grammatical definition).

What's interesting is that the statement "the objectifying tendency ... threatens subjectivity" could be argued no matter what definitions are adopted. Giving both the grammatical definition creates the argument generally used by anti-objectification theorists: that treating someone as an object threatens their status as a subject, an autonomous actor. See supra notes 9-11, and surrounding text. Similarly, defining objectifying grammatically could threaten epistemological subjectivity insofar as the inertness of an object cannot create the dynamism needed for a contingent social sphere. See supra notes 13-14 and surrounding text. Finally, defining both terms epistemologically echoes Dostoevsky's argument against rationalism: that once everything becomes knowable and true, man effectively "has neither will, nor caprice, nor did he ever have them, and that he is nothing more than something in the nature of a piano-key or an organstopFalse" Fyodor Dostoevsky, NOTES FROM THE UnDERgRound 25 (Oxford UP 1991) (1864). 
with inherent value and worth - may or may not be seen as "objectively true" so to speak, but it is perhaps the closest thing to a generally accepted moral proposition out there. ${ }^{83}$ At the very least, the premise that individuals are actors and agents (with all the dignity implications that entails) is seen as something that one possesses inherently, without having to prove or earn it. Hence, we are left with a rather bizarre formulation: objective worth is subjective, and subjective worth is objective.

How these two related but distinct meanings unraveled from each other is beyond the scope of this essay. However, as I use the terms, both "objective" and "subjective" and their derivatives carry meanings closer to the grammatical definitions. "Subjective" worth is worth that one possesses intrinsically, inside themselves, regardless of how others view or treat them. This sense of selfpossession is seen as essential to have the ability to truly act upon the world. "Objective" worth is instrumental worth, it manifests when others find use for us in their own projects. While (to stress again) nobody wants to be valued either solely in their capacity to act or their desirability to be acted upon, these two poles provided the grounding for a clear understanding of the concept of subjectification.

\section{SUBJECTIFICATION IN AMERICA}

As argued in the previous section, while objectification still is a very real problem for people of color, subjectification (being valued solely in terms of one's intrinsic human worth, with no regard for one's ability to contribute to the projects of others) poses a significant threat to one's full sense of personhood as well. This risk is more than just theoretical. As classical forms of racism have diminished in prevalence and salience, the problem of subjectification has waxed considerably. At the same time, American political thought provides ample ammunition for countering this destructive belief. The descriptive claim that heterogeneous social institutions provide important benefits has a well-developed pedigree in this nation, one that can bolster the normative defense of the objective importance of all of America's citizens.

\section{A. Diversity and the Problem of Subjectification}

At root, subjectification is the claim that a given person or group of persons is functionally unnecessary to the wellbeing and flourishing of wider society. For example, though immigrants play a crucial role in the maintenance of the American economy, anti-immigration backlashes typically proceed as if

83. See, e.g., Jean Hampton, An Expressive Theory of Retribution, in RETRIBUTIVISM AND ITS CRITICS 1, 12 (Wesley Cragg ed. 1992) ("[F]ollowing Kant I will assume that this equal value is objective, intrinsic to our nature as persons, and incapable of being lost unless we lose our very humanity."). 
America could dispense with alien workers and suffer little to no ill effects. ${ }^{84}$ In response, immigrant advocates organized what they called "the great American boycott," where immigrants would refrain from working, shopping, or otherwise participating in the American economy as a show of their economic strength. ${ }^{85}$ Fundamentally, this was an assertion of objective value; a claim that, contrary to anti-immigrant claims, immigrants play a vital role in American society, and our nation suffers in their absence. ${ }^{86}$

Subjectification becomes especially apparent in the lack of diversity in our social spheres. When certain classes of individuals are not present in the elite circles that govern our society - the movers and the shakers - the message is sent that the missing persons are not necessary for the functioning of those institutions. The world will move and shake without them. It may be true that people might not notice the presence or absence of certain identity characteristics which they do not see as relevant to their personal achievement. ${ }^{87}$ But in American society, it is virtually impossible for racial minorities to overlook their racial status and fail to notice their relative position vis-à-vis Whites. ${ }^{88}$ As a result, those who do not see diversity as an essential good to be pursued ${ }^{89}$ are implicitly arguing that the people being excluded are not necessary. This message, in addition to being descriptively inaccurate, has morally pernicious effects. As Natsu Jenga argues

[racial] disparities ... are not just statistics to be measured and pondered by sociologists or turned into sound bites by politicians. They reflect the impact of institutionalized racism on people's daily lives, giving us a glimpse of the harsh realities of living in communities where there is little hope of getting a job or a decent education, where parents are afraid to let

84. See, e.g., Mark Krikorian, Jobs Americans Won't Do, The NATIOnAL ReVIEW ONLINE,(January7,2004) [http://www.nationalreview.com/comment/krikorian200401070923.asp]; Marjorie Connolly, In Polls, Illegal Immigrants Are Called Burden, N.Y. TiMES, April 14, 2006, A16.

85. See, e.g., Monica Davey, With Calls for Boycott by Immigrants, Employers Gird for Unknown, N.Y. TIMES, May 1, 2006, A12; Dan Glaister, US protesters stage one-day boycott over immigrant bill, GUARDIAN, May 1, 2006, pg. 15; Tim Reid, Hispanics down tools to show the natives how vital they are, THE TIMES (LONDON), April 29, 2006, pg. 57.

86. It has been argued that America's treatment and perception of immigrants constitutes a "magic mirror" into how America would treat domestic racial minorities in the absence of constitutional protections. Kevin R. Johnson, Race, the Immigration Laws, and Domestic Race Relations: A "Magic Mirror" into the Heart of Darkness, 73 InDIANA L.J. 1111 (1998). Yet, Black people have observed that their voices are not being sought out in the immigration debate either. See Erin Aubry Kaplan, This time, a silent minority: Why are blacks part of the immigration equation but not the debate? L.A. TIMES, January 17, 2007 , A17.

87. Though this is not as simple as it appears: the example of hair color is often trotted out as a case of an "irrelevant" characteristic, yet we have "benign" negative stereotypes of certain hair colors (most notably blondes), which might gain significantly more salience if particular hair colors were perceived as being relatively excluded from society's upper echelons.

88. Jenga, supra note 56, at 1513.

89. Diversity does not occur naturally in a hitherto segregated society. It must be pursued. See Sheryll CAShin, The Failures of InTEgration: How RaCe AND Class are UNDERMINING THE AMERICAN DREAM 71 (2004). 
their children play outside, where many young men do not expect to live to be twenty. ${ }^{90}$

When young men and women of color look up and see few people like them among the leaders of the free world and, more importantly, that nobody cares about this underrepresentation, the effect is to instill a crushing sense of hopelessness and despair. Asked about the effective segregation of her New York City community, one sixteen-year-old girl simply remarked that most New Yorkers would be "relieved" if they "woke up one day and learned that we [Black residents] were gone, that we had simply died or left for somewhere else...." This is reminiscent of the "nihilism" Cornel West identifies in portions of the Black community, and its oppressive cloud draws sustenance from the subjectification of the Black community. ${ }^{92}$ Diversifying social institutions is an important step in alleviating this affliction.

Persons who would object to the formal exclusion of racial minorities from college admission may nonetheless be entirely content with the underenrollment of these minorities as the straightforward operation of "neutral" meritocratic admissions standards. Affirmative action programs are often seen as the antithesis of individualized, merit-based review. This perspective misunderstands the concept of"merit" and subtly disregards certain contributions minority candidates might be able to make. A focus on minimizing subjectification by properly valuing the objective benefits minority candidates would bring to particular educational, economic, or other social institutions reveals how affirmative action programs enrich rather than undermine standard meritocratic norms. The specifics of these objective benefits will be fleshed out in greater detail below, ${ }^{93}$ but it is important first to unpack one of the critical concepts in this debate: "merit".

While not entirely disconnected from personal attributes like effort or achievement, merit is best understood in terms of one's ability to fulfill particular social needs within specific institutional contexts. ${ }^{94}$ Hard work and demonstrated ability to succeed are often associated with one's ability to fill such a niche, but in absence of such ability these attributes are not "meritorious" in and of themselves. We admit students, hire workers, and elect leaders not to reward people for a job well-done, but because we believe that they can contribute something valuable to the relevant educational, entrepreneurial, or political project.

90. Jenga, supra note 56, at 1517.

91. Quoted in KozOL, supra note 117, at 28-29.

92. CORNEL West, RACE MATters 22-23 (2001) ("Nihilism is . . the lived experience of coping with a life of horrifying meaninglessness, hopelessness, and (most important) lovelessness.").

93. See infra Part II.B.

94. See Kenneth L. Karst \& Harold W. Horowitz, Affirmative Action and Equal Protection, 60 VA. L. REV. 955, 961-63 (1974). 
The concept of merit is of course closely related to one's objective value - does one improve an institution or group relative to the next marginal candidate - and as the primary apologia for underrepresentation of racial minority groups, the concept of meritocracy has come under an increasingly critical lens. For the most part, this controversy has largely focused on whether merit measures something objective about personal aptitude and likely future performance, or whether merit is a socially constructed preference for contingent characteristics which are valuable to already-dominant players. ${ }^{95}$ Though important, this debate elides a crucial characteristic of "merit" in the context of group-representation: the ability to provide value. Understood properly, affirmative action and like programs fit comfortably within even the most traditional conceptions of meritocracy.

The standard way of thinking about merit is to come up with a criteria of past and predicted performance, give the candidates an ordinal ranking based on how well they meet the criteria, and select from the top on down until all the positions are filled. ${ }^{96} \mathrm{~A}$ traditionalist might contend that these criteria are largely fair and objective, albeit sometimes applied in a discriminatory manner. ${ }^{97}$ A critic could contend that the formula needs substantial readjustment - a college should put relatively less weight on test scores and more on overcoming adverse life circumstances, perhaps-which would significantly reorder which candidates are most "meritorious." A radical critic could assert that there are no objective criteria at all and that whatever we pick is a mere subjective expression of our own preferences; she would then presumably argue that we should adopt criteria that favor values of greater inclusion and equality. ${ }^{98}$

95. Compare, e.g., Daniel A. Farber \& Suzanna Sherry, Is the Radical Critique of Merit Anti-Semitic?, 83 CAL. L. REV. 853 (1995) with Daria Roithmayr, Deconstructing the Distinction Between Bias and Merit, 85 CAL. L. REV. 1449 (1997); Richard Delgado, Brewer's Plea: Critical Thoughts on Common Cause, 44 VAND. L. REV. 1 (1991).

96. See, e.g., Justin McCrary, The Effect of Court-Ordered Hiring Quotas on the Composition and Quality of Police, 97 Am. ECON. Rev. 318, 320 (2007) (discussing the traditional practice of polices + departments to hire applicants based on their rank-order in taking an entrance exam).

Randall Kennedy argues that even where a person's race demonstrably "may help one to accomplish something admirable"-e.g., a Black police officer potentially being better able to relate to denizens of a largely Black patrol beat - this characteristic should still not be labeled as "merit" because it is a characteristic the officer was born with. Randall Kennedy, Racial Critiques of Legal Academia, 102 HARV. L. REV. 1745, 1805 n.271 (1989). It is unclear, though, whether Kennedy believes such benefits - regardless of the labels attached to them-can nonetheless validly be considered by decisionmakers considering whom to hire for a particular position.

97. See Farber \& Sherry, supra note 95, at 857 ("We do not contend that the current concept of merit is perfect, nor do we deny that discrimination against some groups has denied them their due rewards. Belief in merit is not incompatible with acknowledging that societal standards can be applied in a discriminatory manner. It is also consistent with an understanding that some groups may not have been given a fair chance to acquire necessary skills.").

98. See, e.g., Roithmayr, supra note 95, at 1492 ("[A]11 merit standards necessarily must defer to subjective, nonrational, culturally- and racially-specific judgments about what constitutes social value."). 
No matter which perspective one adopts, however, a strictly ordinal view of merit will remain inadequate. Rather, college admissions, along with most other processes to create a multi-member group, represents a polycentric problem. A polycentric problem is one where there are multiple potential decision nodes, each of which impacts the utility calculus of all those remaining. ${ }^{99}$ Imagine drafting a new football team. One could say there is an objective criterion that the players who will win the most games for the team are the most meritorious. ${ }^{100}$ Even so, ranking each football player from best to worst and selecting accordingly would be a disaster. Most obviously, a football team needs players at different positions; your first five selections should not all be quarterbacks even if the five "best" players in the pool all play that position. Consequently, declining to select the "best" player remaining does not betray meritocratic commitments because the characteristics of the first choice changes who, in all relevant respects, the best players are. ${ }^{101}$ The fact that your first selection was a QB alters the relative values of each of the remaining choices. ${ }^{102}$ And the problem goes beyond the need for distinct positions: different players may have various personal connections or chemistry, may work better or worse in different styles of offense or defense, and so on and so forth. College admissions are similar; the marginal most meritorious candidate changes depending on all the other students who have been admitted. Nobody wants a freshman class composed entirely of Physics majors.

Viewing merit through this lens matters because it can demonstrate the meritocratic nature of affirmative action even under the most traditional view of the concept. Functionally, the effect of subjectification is to assert that whether a school has one Black undergraduate or five hundred has no inherent bearing on the school's educational mission. A considerable body of evidence, however, suggests that this presumption is untrue and that racial diversity is in fact quite important in constructing high-functioning social groups. ${ }^{103}$ As the institution grows more homogenous, the marginal value of providing diversity increases and candidates with that characteristic become increasingly

99. See Lon L. Fuller, The Forms and Limits of Adjudication, 92 HARV. L. REV. 353, 395 (1978) (defining and discussing the concept of polycentricity).

100. One could also level a critique at this "objective" standard, asserting that the purpose of the team should be to entertain the crowd or make the owner the most money; either of which might alter which players are considered the best selections. Either way, the below analysis would remain the same.

101. Richard Fallon acknowledges that a quality (e.g., high LSAT scores) which may be meritorious in deciding how to allocate certain goods (admission to law school) may have no bearing on others (admission to medical school). Richard H. Fallon, Jr., To Each According to His Ability, from None According to His Race: The Concept of Merit in the Law of Antidiscrimination, 60 B.U. L. REV. 815.822 (1980). While this is no doubt true, it is rarely a binary question-most characteristics are at most sometimes dispositive in determining whether a given person deserves a particular dessert. See Karst \& Horowitz, supra note 94, at 961-63 (defining merit as the capacity to meet social needs and noting that such needs and the capacities necessary to promote them will both vary over time).

102. See Fuller, supra note 99, at 395.

103. See infra Part II.B. 
meritorious compared to others. Affirmative action programs are in this sense somewhat of a misnomer - they are nothing more than a particular attribute of meritocratic decision-making, giving preference to candidates who provide unique or scarce benefits vis-à-vis other members of the applicant pool. ${ }^{104}$

The link between non-diverse institutions and subjectification is equally pronounced in broader discussions of democratic and moral discourse. At its most simple, a clear assertion of indispensability is an important move towards securing democratic inclusion, both inherently and tactically. ${ }^{105}$ Robert Cover writes that "victims whose politics may well fail are nonetheless required to act if they are legitimately to stake a claim to the social world they inhabit." 106 Behaving in this way is a prerequisite towards being treated as both an objective and subjective equal.

But even were that not the case, the necessity of diverse outlooks on the world would continue to present itself. ${ }^{107}$ Iris Marion Young critiques the view that "people are able to understand one another's perspectives because, while not identical, they are similarly shaped, and for that reason replaceable with one another," 108 arguing instead for "an account of the nonsubstitutable relation of moral subjects." ${ }^{109}$ In this view, "[i]t is neither possible nor morally desirable for persons engaged in moral interaction to adopt one another's standpoint." 110 Nonsubstitutability implies that the presence of others is required to be fully responsive to their concerns, because "the only correction to... misrepresentation of the standpoint of others is their ability to tell me that I am wrong about them." 111 She continues to quote Seyla Benhabib's point that " $[\mathrm{n}]$ either the concreteness nor the otherness of the 'concrete other' can be known in the absence of the voice of the other. The viewpoint of the concrete other emerges as distinct only as a result of self-definition. It is the other who

104. See Karst \& Horowtiz, supra note 94, at 962-63.

105. See Robert M. Cover, The Origins of Judicial Activism in the Protection of Minorities, 91 YALE L.J. 1287, 1312 (1982) ("Without vigorous Black protest politics - a claim to be essential participants in the public choices of the day-American race politics might have become like the European Jewish question: politics about the victim group. Such a politics cannot help but betray, even at its best, a dehumanizing pattern.").

106. Id.

107. In other words, the focus on subjectification illuminates both the necessity of persons of diverse backgrounds to the democratic project, as well as the necessity of including these persons as part of a political dynamic which is fully inclusive and respectful of them as persons. See Richard C. Boldt, Public Education as Public Space: Some Reflections on the Unfinished Work of Marc Feldman, 61 MD. L. REV. 13, 51-52 (2002).

108. YOUNG, VOICES, supra note 80, at 44.

109. Id. at 39 .

110. Id.

111. Id. at 45. See also Wilson Jeremiah Moses, Creative Conflict in African American Thought: Fredrick Douglass, Alexander Crummell, Booker T. WASHINGTON, W.E.B. DU BOIS, AND MARCUS GARVEY 189 (2004) ("Scholarship can never provide us with the tools to read the heart of another human being."). 
makes us aware of both her concreteness and her otherness."112 In this way, persons who hold diverse perspectives also hold the key to something indispensable to the democratic project.

The problem is that society does not recognize that this voice is irreplaceable. ${ }^{113}$ Instead, as George Yancy argues, "whiteness admits of no ignorance vis-à-vis the black. Hence, there is no need for white silence, a moment of quietude that encourages listening to the black." 114 This is problematic. Young contends that "[n]ormative judgment is best understood as the product of dialogue under conditions of equality and mutual respect. Ideally, the outcome of such dialogue and judgment is just and legitimate only if all the affected perspectives have a voice." 115 If this position is correct, then the presence of the voice of the Other is a necessary, though not sufficient, aspect of achieving the democratic ideal. ${ }^{116}$ Admittedly, just giving minority groups a seat at the table is insufficient to adequately protect their concerns. However, because nothing can replace the voice of the Other in deliberative discourse, their presence is an indispensable part of the democratic project.

This benefit is often overlooked precisely because an ordinal view of merit where prospective candidates are viewed in isolation from one another renders it invisible. Diversity may be valuable, but there is no such thing as a "diverse" person except by reference to the composition of the class as a whole. ${ }^{117}$ Once a polycentric approach is adopted, an objective view of merit can easily incorporate these values. In the educational context, asking what

112. Young, Voices, supra note 80 , at 45-46 (quoting SEYla BenHaBIB, SituATING THE SELF 168 (1991)).

113. See Karin A. Case, Claiming White Social Location as a Site of Resistance to White Supremacy, in DisRupting White Supremacy From Within: White People on What We NeEd To Do 63, 76 (Jennifer Harvey, et al. eds.) (2004) (“An absolutely critical step for white people is admitting ... that our view of reality is limited and partial and that we need to look outside ourselves, beyond customary white perceptions, for a fuller and more accurate view of realityFalse [This] is uncharacteristic of white consciousnessFalse")

114. George Yancy, Introduction: Fragments of a Social Ontology of Whiteness, in What White Looks Like 12 (George Yancy, ed. 2004). Or, as Carol Gilligan wrote, "If you have power, you can opt not to listen. And you do so with impunity." Feminist Discourse, Moral Values, and the Law-A Conversation: The 1984 James McCormick Mitchell Lecture, 34 BuFF. L. REV. 11, 62 (1985) (Isabel Marcus and Paul J. Spiegelman, moderators; Ellen C. DuBois, Marx C. Dunlap, Carol J. Gilligan, Catherine A. MacKinnon, and Carrie Menkel-Meadow, participants).

115. YOUNG, VOICES, supra note 80, at 59.

116. See Martha Minow, Not Only For Myself: Identity, Politics \& THe LaW 10 (1997) ("Differences among people involve not only ideas and beliefs, but also identities reflecting group experiences. These differences deserve representation.”).

117. This is illuminated by the absurdity of school systems which describe themselves "diverse" when nearly $100 \%$ of their student body is Black. JONATHAN KOZOL, THE SHAME OF the NATION: THE RESTORATION OF APARTHEID SchOOLING IN AMERICA 21-22 (2005). See also Martha Minow, After Brown: What Would Martin Luther King Say?, 12 LEWIS \& ClARK L. REV. 599, 605 (2008) (noting how, in prevailing legal and cultural discourse, “'[d]iversity' could be demonstrated in a school whose entire enrollment consists of non-whites-African-Americans, Hispanics, and South Asians, but no Caucasians; diversity can also be the boast of a school with students from the Balkans, Iran, South Africa, and Spain-without a nonwhite person among them."). 
student body composition will create the most vibrant scholarly dialogue and the most able and effective graduates obviously is dependent not only on the atomistic characteristics of individual students but also on how these characteristics combine and interact with the group as a whole. At that point, the refusal to consider the value persons of color contribute (or would contribute) to our social institutions as part of the processes of allocating prestigious positions or scarce resources is a form of subjectification - and one that conflicts with basic meritocratic principles, to boot. ${ }^{118}$

\section{B. The Anti-Subjectification Turn}

While subjectification is unfortunately a deeply entrenched problem in American society, it is countered by a strong strain of political thought which recognizes the meritocratic value of heterogeneous social institutions. These arguments, dating back to the founding of this country, help buttress the notion that the United States needs to utilize all of its human capital in order to reach its full potential. The subjectification angle adds a normative dimension to this putatively descriptive claim.

The idea that diversity is a positive aspect of democratic and social institutions has deep roots in American history, dating back at least in prototypical form to The Federalist Papers. The argument in favor of the Constitution had to contend with a strong belief amongst early American republicans that only homogeneous communities could develop the necessary public-spiritedness to pursue a common good. ${ }^{119}$ Against this, James Madison's argument on factionalism is an early analogue to modern discussions about diverse representation. ${ }^{120}$ Practically speaking, significant cleavages in outlook and concern will inevitably exist among the people. ${ }^{121}$ The risk of tyranny comes when any one group is allowed to dominate the polity, for this "faction" will be able to impose its preferences unchecked by the rights and desires of the minority. ${ }^{122}$ Consequently, it is better to structure government to at least guarantee all these factions have a voice, rather than enable any one group to dominate. ${ }^{123}$

118. Other than the narrowing class of cases where the Court is willing to recognize the ongoing effects of prior de jure discrimination, such a meritocratic defense of diversity initiatives are perhaps the strongest legal ground remaining to advocates of such programs. See infra Part III.A.

119. See, e.g., 2 The Complete ANTIFederalist 369 (Herbert J. Storing, ed., 1980) (arguing that "In a republic, the manners, sentiments, and interests of the people should be similar. If this be not the case, there will be a constant clashing of opinions, and the representatives of one part will be continually striving against those of the other.").

120. The Federalist No. 10 (James Madison) (Henry Cabot Lodge, ed., 1888).

121. Id. at 53 ("As long as the reason of man continues fallible, and he is at liberty to exercise it, different opinions will be formed.").

122. Id. at $55-56$.

123. Id. at 58-59 (preferring a larger republic with a greater range of representatives precisely because it is more likely to be heterogeneous, thus making it less likely that "a majority of the whole will have a common motive to invade the rights of other citizens"). 
In contrast to the view that a sufficiently public-spirited polity could be trusted to protect the rights and liberty of all, Madison instead held that public liberty required the commingling of persons of different backgrounds, interests, and perspectives, each empowered to defend themselves in the public arena. John McGinnis \& Michael Rappaport make similar claim in asserting the superiority of adhering to the original meaning of the Constitution. ${ }^{124}$ They contend that the supermajoritarian process of enacting the Constitution ensures that its provisions are endorsed by "a diffuse and diverse public," rather than a particular or provincial faction. ${ }^{125}$ The need for widespread consensus means that constitutional drafters will need to forward a product that is at least acceptable to a wide range of different views, which itself encourages hearing the perspective of diverse and differentiated stakeholders. ${ }^{126}$ Hence, to the extent that we do prefer a democracy that is duly protective of the rights and interests of all, the presence of the full plurality of persons who make up the polity become a necessary component. ${ }^{127}$

This insight has persisted to the modern day. In Peters v. Kiff, for example, the Supreme Court faced a situation where a White defendant from Georgia claimed his criminal conviction was unconstitutional because Blacks had been systematically excluded from the jury. ${ }^{128}$ Lower courts had ruled that since the defendant was not himself Black, he could not claim any legally cognizable harm from the exclusion of Blacks. The Supreme Court reversed, with Thurgood Marshall explaining that

When any large and identifiable segment of the community is excluded from jury service, the effect is to remove from the jury room qualities of human nature and varieties of human experience, the range of which is unknown and perhaps unknowable. It is not necessary to assume that the excluded group will consistently vote as a class in order to conclude, as we do, that its exclusion deprives the jury of a perspective on human events that may have unsuspected importance in any case that may be presented. ${ }^{129}$

Justice Marshall made two important observations here. First. he rejected the notion that recognizing the value of marginalized perspectives inherently means believing they all think alike. Instead, his view tracks more closely Iris Marion Young's concept of "perspective"-the idea that a person's social

124. JOHN O. MCGINNIS \& MiChAEL B. RAPPAPORT, ORIGINALISM AND THE GOOD CONSTITUTION (2013).

125. Id. at 27 .

126. Id.at 31 .

127. The fact that the vast majority of constitutional provisions were not enacted under conditions that, in fact, included the entirety of relevant American stakeholders (e.g., Blacks and women) represents a serious challenge to McGinnis \& Rappaport's originalism defense. While they address this challenge in their book, see id. at 100, in my view their response is unsatisfactory. See David Schraub, Originalism and Deliberation, at [Part II.A] (unpublished manuscript).

128. 407 U.S. 493 (1972).

129. Id. at $503-504$. 
location gives them a vantage point on collective problems which conditions but does not determine their responses to them. ${ }^{130}$ If one opens a Jewish newspaper, one will undoubtedly be struck by the breadth of viewpoints presented - in fact, it may be more surprising if one could find two Jews who agreed with one another., Nevertheless, the periodical would still be recognizable as a Jewish newspaper. The same is true for historically Black media organs like The Chicago Defender. In this way, we can speak intelligibly about Black or Jewish political thought while obviously recognizing massive differences in the conclusions drawn by individual Black or Jewish thinkers. This avoids the stultifying presumption that concern about marginalized perspectives degrades individuals of color by presuming that they all think alike.

Second, Justice Marshall detached the justification of including Blacks on juries from the seemingly provincial concern of defending African-American rights. While this is an important function, Marshall's stress on how "excluded group[s]" may have important insights to offer in "any case that may be presented" hinges the functioning of criminal law writ large on the equal participation of all members of society. ${ }^{131}$ Following Marshall, persons of all political persuasions have similarly recognized the necessity of having a diverse array of participants in legal institutions. ${ }^{132}$ From the right, Judge Richard Posner argues in favor of having a diverse judiciary, simply because "[s]uch a judiciary is more representative, and its decisions will therefore command greater acceptance in a diverse society than would the decisions of a mandarin court." 133 On the left, Cass Sunstein has made a similar argument, remarking that "[i]n a system of free expression, exposure to multiple perspectives will offer a fuller picture of the consequences of social acts. This should help make for better law." 134 Particularly in polities where there are significant divisions in interests and conceptions of the good which lie along identity axes, the boost to legitimacy a diverse court could bring would be difficult, if not impossible, to replicate via other means.

A growing body of research is beginning to bear out the meritocratic boons of diversity by demonstrating the ways in which persons who bring heterogeneity to monochrome institutions are making important contributions

130. IRIS MARION YOUNG, INCLUSION AND DEMOCRACY 136-45 (2000) [hereinafter YOUNG, INCLUSION].

131. Kiff, 407 U.S. at 503-04 (emphasis added).

132. See, e.g., Angela Onwuachi-Willig, Using The Master's "Tool” To Dismantle His House: Why Justice Clarence Thomas Makes The Case For Affirmative Action, 47 ARIZ. L. REV. 113, 135-41 (2005) (collecting anecdotal and empirical evidence of the effect that a diverse set of perspectives has on legal outcomes); Sherrilyn A. Ifill, Racial Diversity on the Bench: Beyond Role Models and Public Confidence, 57 WASH. \& LEE L. REV. 405, 405 (2000) (arguing that "diversity on the bench can enrich judicial decision-making by including a variety of voices and perspectives in the deliberative process").

133. Richard A. PoSner, LaW, Pragmatism, AND DEMOCRACY 120 (2003).

134. CASs R. Sunstein, Democracy AND the Problem of Free SPEech 243 (1993). 
to the whole. In his study of the effect of racial diversity in jury deliberations, Samuel Sommers found that not only did diverse juries outperform their racially homogenous peers along every indicator, but the performance gains were attributable to the group as a whole, not merely the additional input of the Black jurors. ${ }^{135}$ This tracks more general research making the provocative claim that "diversity trumps ability"- that at the margins it is actually more productive for institutions to bring together diverse perspectives than it is for them to pursue persons with individually superior qualifications but whose outlook is similar to persons already present. ${ }^{136}$ From a childhood development standpoint, there are important implications that flow from an adolescent having a diverse versus homogeneous peer group. ${ }^{137} \mathrm{~A}$ clear example of the effect diversity has on education was the diminishing racial achievement gap alongside rising White graduation rates and test scores that accompanied the enforcement Brown's integration mandate.. ${ }^{138}$ Ultimately, the "point of integration is not to pursue for its own sake ... although it has its own inherent social benefits." 139 Rather, as Sheryll Cashin argues, we pursue integrated social spaces because we believe that it "is the best route to equal opportunity for everyone," because by doing so "we will come closest to maximizing our collective potential," and because an integrated social sphere is one that "cultivat[es] an ethos where the individual, regardless of race, is respected, embraced, and loved." 140

Finally, but -no less importantly, insofar as we conceptualize a just democratic discourse as being fair to all its constituent parts, the presence of all socially salient groups is an irreplaceable function of democratic institutions. Diversity should be pursued for everyone's sake, not just for the sake of the underrepresented minorities. For one, the responsibility to maintain democratic ideals falls upon us all-it is damaging to be a part of an oppressive social schema, regardless of one's relative position within the hierarchy. ${ }^{141}$ A great

135. Samuel R. Sommers, On Racial Diversity and Group Decision Making: Identifying Multiple Effects of Racial Composition on Jury Deliberations, 90 J. PERSONALITY \& SOC. PSYCH. 597, 608 (2006).

136. Lu Hong \& Scott E. Page, Groups of Diverse Problem Solvers Can Outperform Groups of High-Ability Problem Solvers, 101 PROC. NAT'L ACAD. SCI. 16385, 16385 (2004).

137. See Emily Buss, The Adolescent's Stake in the Allocation of Educational Control Between Parent and State, 67 U. CHI. L. REV. 1233, 1258-76 (2000).

138. JeNNIFER L. HochSCHILD \& NATHAN SCOVRONICK, THE AMERICAN DREAM AND THE PUBLIC SCHOOLS 38-40 (2003).

139. CASHIN, supra note 89 , at 81.

140. Id. See also Minow, supra note 117, at 614 (noting that in many cases, "integration emerged as a goal precisely because diverse people do and should become resources for each other.").

141. See Perry v. Schwarzenegger, No. C 09-02292 JW, slip op. at 8 (N.D. Cal. June 14, 2011) (affirming the denial of motion to recuse) ("[I]t is inconsistent with the general principles of constitutional adjudication to presume that a member of a minority group reaps a greater benefit from application of the substantive protections of our Constitution than would a member of the majority. . . . In our society, a variety of citizens of different backgrounds coexist because we have constitutionally bound ourselves to protect the fundamental rights of one another from being 
deal of White anxiety towards the anti-racism project is that they do not wish to conceptualize themselves as part of an illegitimate social arrangement. ${ }^{142}$ While White people have managed to concoct all sorts of rationalizing procedures as to why they are not implicated in these arrangements, ${ }^{143}$ the only long-term fix for the problem is to end the unjust systems that create it. Social separation "seriously impedes political communication among segregated groups, thus making it difficult to address the wrongs of segregation through democratic political action." 144 But more immediately, the presence of a diverse array of perspectives can enhance the political and social horizons of everyone. ${ }^{145}$ Young presses this point, claiming that when personhood is taken to be universally interchangeable, "[i]t closes off the creative exchange these differences might produce with one another ...."146 The lack of representation does not just make our political system less just, it also makes it less effective by depriving it of the full range of resources our society can bring to bear on its myriad problems. When this happens, people of all backgrounds are harmed, even if some are far less likely to recognize their loss. ${ }^{147}$

Simply put, there are irreplaceable benefits that are conferred by the presence of diverse representation in our political, legal, and social

violated by unlawful treatment. Thus, we all have an equal stake in a case that challenges the constitutionality of a restriction on a fundamental right.").

Eric Goldstein noted this dynamic in the development of relationships between Jews and Blacks during the $20^{\text {th }}$ century, noting that "there was . . . a palpable discomfort with the notion that Jews - who had suffered themselves under the ban of both economic and 'racial' persecution - could be accused of oppressing African Americans by these same means." GoldSTEIN, supra note 71, at 164. Writing in the Crisis, leading Jewish Rabbi Stephen Wise argued that if they continue oppressing Black citizens, "the white race will suffer most... mutilating its own moral nature and sinking to a lowered level of life." Quoted in id. at 71.

142. See Judith H. KATZ, White AwARENESS: HANDBOOK FOR ANTI-RACiSM TRAINING 13 ( $2^{\text {nd }}$ ed. 2003) ("Racism has been diagnosed as a form of schizophrenia in that there is a large gap between what whites believe and what we actually practice, which causes us to live in a state of psychological distress.").

Importantly, while people do not wish to conceptualize themselves as implicated in oppressive systems, this does not necessarily lead them to oppose injustice. Often, it simply causes them to mentally recast the victim as "deserving" of their plight. See Jon Hanson \& Kathleen Hanson, The Blame Frame: Justifying (Racial) Injustice in America, 41 HARV. C.R.-C.L. L. REV. 413, 419-20 (2006). Hanson and Hanson draw from an array of experiments conducted by Melvin J. Lerner on how people respond to perceived injustice in varying situations. The main experiment is summarized in Melvin J. Lerner \& Dale T. Miller, Just World Research and the Attribution Process: Looking Back and Ahead, 85 PsYCHOL. BuLL. 1030, 1031-32 (1978)."““

143. See Nancy Ditomaso, Rochelle Parks-Yancy, Corinne Post, White Views of Civil Rights: Color Blindness and Equal Opportunity, in White Out: The ConTINUING Significance OF RACE 189-98 (Eduardo Bonilla-Silva \& Ashley W. Doane, eds. 2003).

144. YOUNG, INCLUSION, supra note 130, at 205.

145. One example is that recognizing the value of other groups can give the dominant classes a clearer perspective on their own identity, forcing it "to discover itself for the first time as specific." YOUNG, DIFFERENCE, supra note 11, at 166.

146. YOUNG, VOICES, supra note 80 at 45.

147. CASHIN, supra note 89 , at 185 ("The costs of separatism to whites [are] enormous, yet they are the ones who are likely to be least conscious of separatism's insidious effects."). 
institutions. ${ }^{148}$ "There is a point at which the presence of a racial minority becomes substantial enough to catalyze intergroup relations, a 'tipping point' or "critical mass." "149 Presence matters in and of itself;there is no substitution. Because of that, representing an otherwise absent group is itself an aspect of merit. ${ }^{150}$

\section{IMPLICATIONS OF THE ANTI-SUBJECTIFICATION STANCE}

The previous two sections sought to illuminate the idea of subjectification, both conceptually and with reference to the specific controversy over diversifying social and political institutions. This section explains what flows from taking the problem of subjectification seriously. Three major implications spring to mind. First, a focus on subjectification has doctrinal implications in civil rights law. Consistent with the interest-convergence hypothesis, ${ }^{151}$ the focus on how strong civil rights protections aid the entire community (rather than just the putatively aggrieved) has historically been one of the more robust strains of progressive, integrationist legal precedent. ${ }^{152}$ Second, while the meritocratic undertones of the anti-subjectification stance may appeal to the right, concentrating on the problem of subjectification may also rehabilitate the diversity rationale from attacks made by more leftward critics, who believe that this "forward-looking" rationale is not sufficiently attentive to the oppression and mistreatment people of color face today. Unlike the classic rendition of the diversity argument however, the anti-subjectification defense does not shy away from questions of justice or what people or color are due. Much the opposite - it makes a powerful moral claim that persons of all races and backgrounds are owed recognition not just of their technical, subjective rights as citizens, but also of their objective worth as valuable, instrumental players in society. Finally, giving due accord to the problem of subjectification has significant normative implications in terms of how Whites and people of color relate to one another.

148. See Heather K. Gerken, Second-Order Diversity, 118 HARV. L. REV. 1099, 1124-79 (2005) (identifying four key benefits to diversifying democratic institutions so as to enhance minority voices where they otherwise might have been absent or suppressed).

149. Comfort v. Lynn Sch. Comm., 263 F. Supp. 2d 209, 260-61 (D. Mass. 2003).

150. While it is of course only an "aspect"-not the totality - this is consistent with almost all affirmative action programs as practiced, which seek to incorporate the benefits of racial diversity as part of a holistic review of all the prospective candidates.

151. See Bell, supra note 62.

152. It is notable that early efforts to improve the lives of women also took on a mixed approach, emphasizing both the benefits to women themselves, as well as the increased benefits to men that would stem from women's liberation. See SUSAN MOLLER OKIN, WOMEN IN WESTERN Political ThOught 212-13 (1979) (observing that John Stuart Mill's advocacy on behalf of women emphasized not only "the added happiness of women themselves," but also the "most valuable effects" it would have on men). 


\section{A. Anti-Subjectification and the Law}

Integration is normally justified based solely on the idea that the excluded are suffering from a lack or absence - something is missing from their political, educational, or social experience. For example, in McLaurin v. Oklahoma State Regents, the Supreme Court struck down restrictions on a Black student enrolled at an Oklahoma state graduate program that prevented him from interacting with White students in the same program. ${ }^{153}$ Specifically, McLaurin was forced to sit in a separate row in class, a separate table at lunch, and a separate study area in the library. ${ }^{154}$ Ruling that these conditions were unconstitutional under the $14^{\text {th }}$ Amendment, Chief Justice Vinson argued that "The result [of these restrictions] is that appellant is handicapped in his pursuit of effective graduate instruction. Such restrictions impair and inhibit his ability to study, to engage in discussions and exchange views with other students, and, in general, to learn his profession." 155 Nowhere was it indicated, or did it even seem to occur to the Court, that White students lacking McLaurin's perspective and experience might be impaired in their ability to grasp the full reach and practice of their area of study. ${ }^{156}$

Sweatt v. Painter, decided the same day as McLaurin, faced a similar question and gave a similar answer. ${ }^{157}$ In Sweatt, the petitioner was denied admission to the all-White University of Texas law school. He was advised instead to seek enrollment in a newly established Black law school, one which had significantly fewer students, faculty members, and resources, and also lacked in the more intangible but equally important factors of prestige and credibility within the Texas legal community. ${ }^{158}$ Emphasizing that "The law school to which Texas is willing to admit petitioner excludes from its student body members of the racial groups which number $85 \%$ of the population of the State and include most of the lawyers, witnesses, jurors, judges and other officials with whom petitioner will inevitably be dealing when he becomes a member of the Texas Bar," the Court unanimously held that Sweatt be admitted to the University of Texas law school. ${ }^{159}$ The Court was undoubtedly right that it "overlooks realities" to assert that the barring of White students from the allBlack law school is the legal or moral equivalent of the prohibition on Black students attending the all-White program. ${ }^{160}$ Nonetheless, it is unreal to suggest

153. 339 U.S. 637 (1950).

154. Id. at 640 .

155. Id. at 641 (emphasis added).

156. See Goodwin Liu, Affirmative Action in Higher Education: The Diversity Rationale and the Compelling Interest Test, 33 HARV. C.R.-C.L. L. REV. 381, 387 (1998) (Sweatt and McLaurin "framed the value of racial integration in terms of what black students could learn through interaction with their white peers, without also mentioning what white students could gain by going to school with blacks."). ““”

157. 339 U.S. 629 (1950).

158. Id. at 632-34.

159. Id. at 634 .

160. Id. 
that something is not missing from the education of a White law student in Texas and Oklahoma when a significant portion of their fellow citizens are excluded from adding to their knowledge and understanding of the legal field. ${ }^{161}$ This perception has not dissipated in subsequent years. Even Derrick Bell, founder of the Critical Race Theory movement, described "the actual presence of white children" as "essential to the right [of school desegregation] in both its philosophical and pragmatic dimensions." 162

It was precisely for that reason that Black writers ranging from Malcolm $\mathrm{X}$ to Clarence Thomas have viewed integrationist practice as patronizing and degrading - it rendered African Americans parasites who, in effect, needed the civilizing presence of Whites while contributing nothing valuable in return. In his indictment of prevailing integrationist politics, Malcolm wondered why "if white people can go to a white classroom and there are no Negroes present and it doesn't affect the academic diet they're receiving, [why] an all-black classroom can be affected by the absence of white children." The message of integration "is that the whites are so much superior that just their presence in a black classroom balances it out."163 In Missouri v. Jenkins, Justice Thomas'

161. It is worth noting that, somewhat surprisingly, there were strong voices in favor of integrating graduate programs within the White student body and faculty in both Texas and Oklahoma. "Two thousand white students and faculty members rallied in support of Sweatt's suit against the University of Texas Law School, and white students there organized a college chapter of the NAACP - the only all-white branch in the country." MiCHAEL J. KLARMAN, From JiM Crow to Civil Rights: The Supreme Court and the Struggle for RaCial Equality 210 (2004). When, in a prior case, a Black student had sued for admission into the University of Oklahoma law school, Sipuel v. Board of Regents of the University of Oklahoma, 332 U.S. 631 (1948), "a thousand white students demonstrated in her support." KLARMAN, supra, at 210. Overall, "Opinion polls conducted at these universities showed substantial - even majoritysupport among students for integration." Id.

162. Derrick Bell, Serving Two Masters: Integration Ideals and Client Interests in School Desegregation Litigation, 85 YALE L.J. 470, $477-78$ (1976) (emphasis added). Interestingly, one of the few authors to refer to the damages White children face when attending segregated schools does so in the context of advocating "limited separation" anyway. BROOKS, supra note 76, at 3132 ("[I]ntegrated schools are better suited for middle-class African American children. True, there are not enough middle-class African American children to go around, and some white children will, therefore, miss out on a valuable life experienceFalse But on the other hand, scores of African American children will gain their dignity and perhaps some education.").

Bell himself later noted the harms segregation perpetuated on White children in one of his reconceptions of the Brown opinion. He would have including a section noting "that segregation perpetuates the sense of white children that their privileged status as whites is deserved rather than bestowed by law and tradition. We hold that racial segregation afflicts white children with a lifelong mental and emotional handicap that is as destructive to whites as the required strictures of segregation are to Negros.” DeRrick BELl, SILENT COVENANTS: BROWN V. BOARD AND THE UNFULFILlED HOPES FOR RACIAL REFORM 23 (2004). Bell, however, has become disenchanted with the entire promise of Brown, and now expresses preference for strict enforcement of Plessy $v$. Ferguson's "separate but equal" doctrine. See id., 21-27; Derrick Bell, Derrick A. Bell, Dissenting, in What BROWN V. BOARD OF EDUCATION SHOUld HAVE SAID: THE NATION's TOP Legal EXPERTS Rewrite AMERICA's LANDMARK Civil Rights DeCision 185-200 (Jack Balkin, ed. 2001).

163. Malcolm X, By Any Means Necessary: Speeches, InTERVIEWS AND a LetTer 16-17 (George Breitman ed., 1970). 
scathing concurrence echoed these concerns-by defining integration's benefits solely with respect to the supposed deficiencies in Black students, the Court was suggesting that "anything that is predominantly black must be inferior." 164 "[T]here is no reason to think that black students cannot learn as well when surrounded by members of their own race as when they are in an integrated environment." 165 Without the language to speak about the instrumental value of racial minorities from within an anti-racist perspective, integration becomes a patronizing indulgence the White majority deigns to grant to people of color, and these critiques become quite difficult to answer effectively.

But several cases have broken from this mold by correctly identifying that the whole of society is harmed by exclusionary policies, not just the targets of exclusion. ${ }^{166}$ For example, while the Supreme Court wrote in Washington $v$. Seattle School District No. 1 that "desegregation of the public schools ... at bottom inures primarily to the benefit of the minority...."167, the Court continued on to write that desegregated public schools might "teach[] members of the racial majority to live in harmony and mutual respect with children of minority heritage." 168 The argument was pressed even further in Trafficante $v$. Metropolitan Life Insurance Company, which was decided the same year as Peters. In that case, the Supreme Court upheld a suit by White residents of an apartment complex regarding racial discrimination against non-Whites by their landlord. ${ }^{169}$ After losing at both the trial and appellate level, the Supreme Court unanimously held that such a claim could proceed under the Civil Rights Act of 1968. In doing so, the Court cited legislative history indicating that "The person on the landlord's blacklist is not the only victim of discriminatory housing practices; it is ... 'the whole community," ${ }^{170}$ and that the purpose of the act was to produce "truly integrated and balanced living patterns." 171 The specific harms articulated by the White tenants are also striking in the degree to which they portray living in an integrated community as necessary to their full and complete flourishing - tangibly and intangibly. Specifically, the tenants argued that, insofar as their residency discriminated against non-Whites, "(1) they had lost the social benefits of living in an integrated community; (2) they had missed business and professional advantages which would have accrued if they had lived with members of minority groups; (3) they had suffered embarrassment and economic damage in social, business, and professional

164. Missouri v. Jenkins, 515 U.S. 70, 114 (1994) (Thomas, J., concurring).

165. Id. at $121-22$.

166. Prior to the emergence of these cases, W.E.B. Du Bois expressed a similar belief in more pessimistic circumstances. Predicting that the American South would successfully resist the Brown v. Board decision, Du Bois warned that this would "ruin the education of millions of black and white children." W.E.B. Du BoIS, The AutoBiograPhy OF W.E.B. Du Bois: A SOLILOQuY ON VieWING My LiFE FROM THE LAST DECADE OF ITS FirST CENTURY 333 (1968).

167. 458 U.S. 457, 472 (1982), and, the Court added, "is designed for that purpose." Id.

168. Id. at 473 (internal quotations omitted).

169. 409 U.S. 205 (1972).

170. Id. at 211 (quoting Senator Javtis).

171. Id. (quoting Senator Mondale). 
activities from being 'stigmatized' as residents of a 'white ghetto." 172 The objective benefits of heterogeneity were thus spread across all racial groups. Five years later, in Linmark Associates v. Township of Willingboro, ${ }^{173}$ the Court proclaimed that "promoting stable, racially integrated housing" was a "vital goal", and reiterated Trafficante's observation that "substantial benefits flow to both whites and blacks from interracial association." 174

Paired with cases like Kiff, ${ }^{175}$ there is considerable vitality in arguments predicated off the necessity of inclusion to achieving a desired social end. Even conservative judges have upheld race-based affirmative action programs when insuring some non-marginal racial representation could be shown to be instrumental to the success of a governmental program. ${ }^{176}$ In Wittmer v. Peters, for example, the $7^{\text {th }}$ Circuit in an opinion by Judge Richard Posner upheld a race-conscious hiring policy by a state run "boot camp" for inmates against challenges by three rejected White applicants. In doing so, Judge Posner took notice that the camp administrators "did not rely on generalities about racial balance or diversity.... [rather] [t] hey opined that the boot camp in Greene County would not succeed in its mission of pacification and reformation ... if a black male had not been appointed to one of the lieutenant slots." ${ }^{177}$ Arguments that stress the necessity of Black representation in important governmental and social institutions are thus significantly stronger-from a legal as well as moral point of view - than those which provide merely generic appeals to diversity.

It is no accident that the language of instrumental value is effective where other arguments fail. Interest-convergence is of course a part of this story, and I maintain that is not a negative one insofar as it provides a blueprint towards attaining at least some measure of otherwise elusive racial-justice. ${ }^{178}$ But beyond that, a recurrent thread in Supreme Court precedents about affirmative action is the view that any usage of race is antithetical to the treatment of persons as individuals. ${ }^{179}$ Of course, this mantra alone says little- $\mathrm{I}$ am as individually White as I am individually Jewish as I am individually someone with (I hope) a talent for writing. The idea, though, is that only some of these characteristics are useful to the projects of others (i.e., carry with them objective value) and are properly considered when competing for scarce resources (such as college admissions slots or government contracts). Race can justly be excluded from consideration because of the presumption that it is never a characteristic with valid objective value.

172. Id. at 208 .

173. 431 U.S. 85 (1977).

174. Id. at $94-95$.

175. See supra notes $128-131$ and surrounding text.

176. See Wittmer v. Peters, 87 F.3d 916 ( $7^{\text {th }}$ Cir. 1996).

177. Id. at 920 .

178. See supra note 68 and surrounding text.

179. See, e.g. Miller v. Johnson, 515 U.S. 900, 911 (1995) ("[T] he Government must treat citizens as individuals, not as simply components of a racial, religious, sexual, or national class."). 
But if one's racial background does have instrumental value, then it is harder to justify blanket proscriptions on public consideration of its utility-our race becomes another element of the cocktail of qualities we bring to the table, one more attribute of our individuality. In effect, maintaining a sharp bifurcation between purely personal, "subjective" identity elements (such as race) and instrumental, publicly-oriented ones (such as academic prowess) acts to deprive racial minorities of an important mechanism of public participation. At the same time, it forces affirmative action advocates to rely upon arguments the courts have already demonstrated a marked skepticism towards.

\section{B. Rehabilitating Diversity}

Though the most prominent opponents of diversification lie on the right, the diversity rationale (if not diversification itself) has leftward critics as well. In the wake of Proposition 209 and other like assaults on affirmative action, Charles Lawrence III penned an article articulating his discomfort with what he terms the "liberal defense of affirmative action," commonly known as the diversity rationale. ${ }^{180}$ While recognizing the "strong strategic reasons" 181 in favor of holding to this approach, Lawrence does not believe it offers the truly radical critique of the current racial situation that is demanded. He groups the diversity argument for affirmative action as a "forward-looking" argument that does not adequately state or defend the interests of the subordinated. “"[F]orward-looking' arguments for affirmative action make sparing reference to past or current wrongdoing, and instead defend affirmative action as a means to some desirable future goal. The liberal or 'diversity' defense articulates its purpose as 'forward-looking' rather than 'backward-looking.' In so doing, it begins with an implicit denial of the defender's participation in or responsibility for past or contemporary racism." 182 "This denial," he argues, "concurs in and reiterates 'the big lie,' the anti-affirmative action argument that pretends that white supremacy is extinct and presupposes a color-blind world, a world in which race-conscious remedies become invidious discrimination." 183

It is true that the classical offering of the diversity argument makes only a sparing connection to the ongoing social oppression of racial minorities. ${ }^{184}$ But, presented properly, the diversity rationale need not accede to this false history

180. Lawrence, supra note 60, at 931.

181. Id. at 958 .

182. Id. at $952-53$.

183. Id. at 953 (footnote omitted).

184. See Paul Gewirtz, The Triumph and Transformation of Antidiscrimination Law, in RACE, LAW, AND CUltuRE: REFLECTIONS ON BROWN V. BOARD OF EDUCATION 110, 126 (Austin Sarat ed., 1997) (Compared to the remedial justification, which "is rooted in our country's shameful history of racial wrongs," the diversity rationale rests its case on "a weaker and debatable instrumental claim that promoting greater diversity will make various programs and institutions function better."). 
of the world. ${ }^{185}$ The framing of diversity as necessary to remedy the past and ongoing subjectification of people of color gives it the "backward-looking" stance Lawrence believes more effectively buttresses and defends the affirmative action project. ${ }^{186}$ The argument is that a college or university cannot effectively perform its role without the active presence and participation of all races, and that a particular form of ongoing oppression is posing a barrier to that end. ${ }^{187}$ Far from being optional, the presence of people of all racial backgrounds is instrumental to the success of the college as an institution. ${ }^{188}$ In this way, the focus on subjectification offers a hitherto-missing piece of the puzzle. It synthesizes the well-established descriptive benefits of diversity with an important and compelling normative vision of what people of color are due, of what it means to recognize the entire panoply of attributes associated with full personhood.

The anti-subjectification argument assumes, at its very core, that contributing to diversity is part of what makes a meritorious applicant. There is a positive element to this claim, but there is a normative one as well. First, it no longer renders the program or its beneficiaries as exceptional. Often times, Susan Sturm and Lani Gunier write, "employers and universities often publicly announce affirmative action programs and justify deviations from their 'normal' practices in terms of affirmative action." 189 Affirmative action is an

185. Professor Lawrence agrees. See Charles R. Lawrence III, Each Other's Harvest: Diversity's Deeper Meaning, 31 U.S.F. L. REV. 757, 765-66 (1997) (arguing that articulating how diversity can undermine racist structures allows for the linkage between the backward- and forward-looking rationales for affirmative action).

186. See Lawrence, supra note 60, at 952-54; Young, DIFFERENCE supra note 11, at 194 ("Justifying affirmative action policies as redress or compensation for past discrimination is fairly uncontroversialFalse").

187. See, e.g., Dinesh D'Souza \& Christopher Edley, Jr., Affirmative Action Debate: Should Race-Based Affirmative Action Be Abandoned as a National Policy? 60 ALB. L. REV. 425, 436 (1996) ("[W]hen the Chicago Police Department wants to use affirmative action to have more police officers who can work more effectively in the African-American or the Latino communities, it is doing so in part because the police department is trying to overcome its own history of discrimination. But the police department is also doing it because they recognize that the Chicago police will do a better job as a law enforcement agency if its diversity to some extent reflects the diversity of the community they are trying to serve. The organization will be better if it is more inclusive.").

Cf. Sweatt v. Painter, 339 U.S. 629, 634 (1950) ("The law school, the proving ground for legal learning and practice, cannot be effective in isolation from the individuals and institutions with which the law interacts. Few students and no one who has practiced law would choose to study in an academic vacuum, removed from the interplay of ideas and the exchange of views with which the law is concerned.").”“

188. Research has begun to show that diversified groups do in fact perform better than their segregated peers. See Sommers, supra note 135 (finding that diverse juries have measurably superior deliberations to racially homogenous peers); Hong \& Page, supra note 136. Joshua Wilkenfeld argues that this sort of evidence could be used to justify proactive efforts to diversify jury panels in the wake of Grutter v. Bollinger, 539 U.S. 306 (2003). See generally Joshua Wilkenfeld, Note, Newly Compelling: Reexamining Judicial Construction of Juries in the Aftermath of Grutter v. Bollinger, 104 COLUM. L. REV. 2291 (2004).

189. Susan Sturm \& Lani Guinier, The Future Of Affirmative Action: Reclaiming The Innovative Ideal, 84 CAL. L. REV. 953, 999 (1996). 
exception to general procedure- the implication being that had normal ("fair") procedures been followed, the employees targeted by affirmative action never would have been hired. There is no reason whatsoever to make this concession. As Judith Katz notes, affirmative action policies in the business world are "not primarily a reaction to legal and social pressures; [they are] a bottom-line productivity initiative predicated on the notion that differences in experiences, points of view, skills, styles, interests, and so forth, are enriching and valuable." ${ }^{190}$ In other words, they are implemented because they make the company a better, more productive business. Integrating affirmative action into the overall conception of merit halts the damaging perception that diversifying an institution is a goal which stands in opposition to hiring the best possible work force. Instead, it is an indispensable part of hiring the best possible work force.

Second, it also is revolutionary in terms of how it conceptualizes the role of racial-minority status. Randall Kennedy declares that "[t]his is the most striking and historically significant aspect of affirmative action: It enables racial-minority status for the first time in American history to be seen as a valuable credential. Instead of the presence of blacks and other racial minorities constituting an expiation of past sins, the diversity rationale makes their presence a welcome and positive good." 191 For a community that has so long been seen within American society as extraneous at best, parasitic at worst, this is a significant advance.

It is true that this justification for affirmative action does seem to stop once the requisite number of minority students or bankers or lawyers have been obtained-once we've achieved the "necessary" amount. Indeed, even the virulently prejudiced have accepted that a limited amount of certain minority groups can be useful to society - a position they hold in tandem with racist beliefs and a generally exclusionary attitude. ${ }^{192}$ But it does not follow that affirmative action must become "a homeostatic device." 193 First of all, this would only hold true if affirmative action could only be justified via the concept of objective worth. But, as I have emphasized, this essay is not designed to erase the importance of one's inherent, subjective worth as a person, only to raise consciousness of another important aspect of one's personhood. A college which, at any point, simply refused to fairly consider admitting another non-White student would be impinging on that person's subjectivity, even if the school was committed to the idea that students of color

190. KATZ, supra note 142 , at 12.

191. Randall Kennedy, The Enduring Relevance of Affirmative Action, AM. РROSPECT, Aug.112010,availableat

http://www.prospect.org/cs/articles?article=the_enduring_relevance_of_affirmative_action .

192. Charles Lindbergh, a notorious anti-Semite, brought a ship full of Jewish refugees into New York in 1939. He wrote "A few Jews add strength and character to a country, but too many create chaos." Quoted in GOLDBERG, supra note 71, at 132.

193. Richard Delgado, Affirmative Action as a Majoritarian Device: Or, Do You Really Want To Be a Role Model? 89 MICH. L. REV. 1222, 1224 (1991). 
were objectively valuable. ${ }^{194}$ But perhaps more importantly, at this point the problem is more theoretical than real. The threshold at which currently underprivileged groups would cease being valuable is both (obviously) above their status quo representation, but also well above the current unspoken caps on affirmative action, which tend to be at the point where White people stop feeling guilty and start feeling scared. ${ }^{195}$ Incorporating people of color to the point where their voices play a substantive and meaningful role in the directing and direction of our educational institutions would be a radical shift. We do not know what the world would look like. Consequently, it would seem prudent to hold off on addressing the potential problem of future retrenchment until after we overcome the current set of hurdles.

\section{Anti-Subjectification and Society}

By sending a message that White people cannot do it alone, that all of us have intrinsic and instrumental worth, the anti-subjectification critique of the anti-diversity position can help reverse the damaging sentiment that non-White lives don't matter, are worthless, and that their absence is not one at all. ${ }^{196}$ That White people benefit from diversity is merely part of a larger argument being made here - that all are reliant on all, and that, far from being a patronizing indulgence, grasping our full potential as human beings is dependent on recognizing others. ${ }^{197}$ As Audre Lorde argues:

[D]ifference must be not merely tolerated, but seen as a fund of necessary polarities between which our creativity can spark like a dialectic. Only then does the necessity for interdependency become unthreatening. Only within that interdependency of different strengths, acknowledged and equal, can the power to seek new ways to actively 'be' in the world

194. I am not arguing that there is no risk to this occurring. As Derrick Bell has noted, outside both objectification and subjectification there seems to be an "unspoken limit" on affirmative action at which point minority representation becomes too much. See Derrick Bell, The Unspoken Limit on Affirmative Action: The Chronicle of the DeVine Gift, in AND WE ARE Not SAVED: The Elusive Quest For RaCial Justice 140-61 (1987). However, it is at least beneficial to disentangle the separate practices which act to restrict the opportunities available to people of color.

195. Delgado, supra note 193, at 1224.

196. For a particularly stark exploration of this belief, see Derrick Bell, The Space Traders, in Faces at the Bottom of the Well: The Permanance of RACism 158-94 (1992).

197. For example, Buchanan v. Warley, 245 U.S. 60 (1917), invalidated racial zoning laws as infringing on the property rights of Whites - namely, to sell to Black homeowners. Robert Cover describes the case as "one of the few areas in which the Court had already acted to protect Black interests, if not rights" prior to Carolene Products' famous footnote four. Cover, supra note 105 , at 1305. That judicial protections for Black citizens began with attention to White rights is unsurprising given Professor Bell's interest-convergence thesis. Bell, supra note 62. But it is worth noting the undertones of a fuller liberationist practice: Whites cannot fully exercise their endowed constitutional and human rights unless they likewise extend protections and equal treatment to Blacks. 
generate, as well as the courage and sustenance to act where there are not charters. ${ }^{198}$

When difference is necessary, those who are different become indispensable. ${ }^{199}$ President Obama's 2013 graduation speech at Morehouse College emphasized this theme. Much of the President's speech focused on the need for the Black community, and Black men in particular, to look inward-to expect more of themselves and to serve as a role model for others. ${ }^{200}$ But he concluded by urging the graduates to do these things "not just for yourself," and not even "just for the African American community," because "it's not just the African American community that needs you. The country needs you. The world needs you." ${ }^{201}$ The experience of being Black men in society, people who have faced marginalization and struggle, was objectively valuable to the world at large because it "should endow you with empathy - the understanding of what it's like to walk in somebody else's shoes, to see through their eyes, to know what it's like when you're not born on 3rd base, thinking you hit a triple." ${ }^{202}$ Such a perspective is needed not just because of what it does for any individual as a moral subject, but is valuable for what it can teach the nation and the world. And properly valuing that ability to contribute is as important as respecting the individual subjective value of the Black community.

Admittedly, constructing a policy predicated on identifying non-Whites as "different" from Whites can have the effect of making White people the norm, contributing to the otherization of racial minorities. But not necessarily. Martha Minow notes that "Difference . . is a comparative term. It implies a reference: different from whom? I am no more different from you than you are from me." ${ }^{203}$ But Lorde's point is that difference is a source of power, not weakness, and her reference to the "polarities" of difference implies that all parties in a relationship - equally different from each other - use those distinctions to spark new and creative ways of seeing the world. In the context of the American racial system, White people occupy a different space than non-White people, and non-White people occupy a different space than White people, but neither one can be dispensed with if our institutions and citizenry are to reach their full

198. Audre Lorde, The Master's Tools Will Never Dismantle The Master's House, in THIS BRIDGE CALLED MY BACK 99 (Cherrie Moraga \& Gloria Anzaldua, eds. 1981).

199. See Minow, supra note 117, at 604 ("Diversity should enlarge the integration ideal to be fully inclusive and could embed racial mixing in the attitude of appreciation for different backgrounds and perspectives.").

200. Barack Obama, Transcript: Obama's Commencement Speech at Morehouse College, WALl ST. J. (May 20, 2013), available at http://blogs.wsj.com/washwire/2013/05/20/transcriptobamas-commencement-speech-at-morehouse-college/ .

201. Id.

202. $I d$.

203. Martha Minow, Making All the Difference: Inclusion, Exclusion, and AMERICAN LAW 22 (1990). 
potential. The mistake occurs when certain groups are presented as normal, whole, and complete, and others as variant, exotic, and special. ${ }^{204}$

The hope of an anti-subjectification perspective, then, is that it will convince people of all backgrounds of the benefits of a diverse and flourishing social sphere. It is this dream which the Parents Involved plurality, striking down voluntary and democratically-supported school integration efforts, might threaten most. By condemning these efforts as "racial balancing," a violation of the $14^{\text {th }}$ amendment, ${ }^{205}$ Chief Justice Roberts and his cohorts would actively hinder the emergence of a progressive consensus that sees diversity as a necessity for themselves and their children. ${ }^{206}$ Even if this cadre is in the minority now, it is no small thing to smash its development-and furthermore, it prevents other communities from seeing and building on that progress. ${ }^{207}$ Fortunately, Justice Kennedy's concurrence forestalls that foreboding day. And since courts tend to be responsive to majority pressure in favor of protecting minority rights, a concerted effort to create a vocal White coalition that sees integration as in its own interests could reverse the anti-integration legal trend before it is too late..$^{208}$

\section{CONCLUSION}

People have a real and powerful need to see themselves as filling a useful role in society. They desire recognition, and "Most of our society's productive and recognized activities take place in contexts of organized social cooperation... social structures and processes that close persons out of participation in such social cooperation are unjust." ${ }^{209}$ Due respect for the fullness of personhood requires accounting for both one's subjectivity-as a unique human being with unconditional value and worth, and one's objectivity - as a person who has instrumental value to others and the overall functioning of society.

204. Criticizing the prevalent dynamic in interracial groups wherein people of color are supposed to serve as "teachers" for White people, Judith Katz argues that "[t]he overall tone ... must be one of sharing and learning together, instead of one group bearing the burden of educating the other." KATZ, supra note 142, at 20.

205. Parents Involved, 551 U.S. at 732 ("While the school districts use various verbal formulations to describe the interest they seek to promote-racial diversity, avoidance of racial isolation, racial integration - they offer no definition of the interest that suggests it differs from racial balance.").

206. See David Schraub, Our Divine Constitution, 44 LOY. U. (CHI.) L.J. 1201, 1258-59 (2013) ("The panic caused by Parents Involved is not just the tangible fact that Seattle and Louisville cannot voluntary integrate their schools, but the prospect that our citizenry will come to understand the project of school integration as an evil itself.").

207. See Ryan, supra note 68, at 155-56.

208. See Jack M. Balkin, What Brown Teaches Us About Constitutional Theory, 90 VA. L. REV. 1537, 1553 (2004) ("All other things being equal, the most effective way for minorities to secure protection by courts and legislatures is for the minority group to demonstrate that protection of its rights is in the interest of majoritiesFalse Then courts, which tend to reflect the views of the dominant national political coalition, will follow suit.").

209. YOUNG, DIFFERENCE, supra note 11, at 55. 
The argument of this essay is not to "reclaim" objectification by trying to argue that what people really and solely desire is adequate respect for their objectivity. Recognizing the indispensability of certain persons, even in a positive sense, without due consideration for their subjectivity can lead to morally perilous stances as well. For example, a statement by a college that "we need Black people to function effectively — any Blacks will do" would not subjectify Blacks, but it would objectify them. This impresses the need to actively defend object- and subject-status simultaneously. Granting either one, without the other, simply switches the axis of oppression - it changes the scale, but it still prioritizes the bodies. It will be difficult to balance these two competing demands against each other-but acknowledging the problem is a good first step. ${ }^{210}$ Recognizing the need to affirm the objectivity and subjectivity of all persons opens the doors to a more nuanced, complete antiracism practice that can help restart the civil rights project in the new millennium.

210. See Martha Nussbaum, On Moral Progress: A Response to Richard Rorty, 74 U. CHI. L. REV. 939, 940 (2007) ("[T] he exposure of . . behavior as what it is, the sheer naming of it as oppression, and the existence of widespread public argument about it, changes things for good...."). 